\title{
LOS MÚSICOS EN LA FESTIVIDAD DEL CORPUS DE SEVILLA ENTRE LA BAJA EDAD MEDIA Y EL RENACIMIENTO' ${ }^{1}$
}

\author{
MUSICIANS IN THE FESTIVITY OF CORPUS IN SEVILLE \\ BETWEEN THE LATE MIDDLE AGES AND THE RENAISSANCE
}

\author{
Clara Bejarano Pellicer \\ Universidad de Sevilla
}

\begin{abstract}
Resumen: Este artículo aborda las primeras referencias históricas a los músicos en la ciudad de Sevilla, que se encuadran cronológicamente desde la Baja Edad Media hasta aproximadamente 1525. El objetivo de este estudio consiste en perfilar los orígenes y antecedentes institucionales de las estructuras típicas de la Modernidad en lo que a aspectos musicales se refiere, para comprobar en qué medida las tendencias apuntadas se consolidaron o se transformaron en el período posterior, ya bien entrado el siglo XVI. La festividad del Corpus constituye un entorno privilegiado de observación. Para ello, se recurre a fuentes archivísticas, narrativas y bibliográficas combinadas.
\end{abstract}

Palabras clave: música; capilla; ministriles; cantores; Corpus Christi; fiestas públicas; órgano.

\begin{abstract}
This paper presents early historical references, dating from the late Middle Ages to about 1525, regarding musicians who worked in Seville. The aim of this research is to clarify the institutional origins of Early Modern musical structures in the city. The changes between those traditions that continued to be observed and new trends will be analysed for the period in question as well as their legacy for the late sixteenth century. The feast of Corpus Christi provides an exceptional observational point. This analysis is based on a variety of historical sources, including archival, narrative and bibliographical.
\end{abstract}

Keywords: music; music chapel; minstrels; choristers; organ; Corpus Christi; public feasts; royal entries.

\section{SUMARIO}

1. La música eclesiástica.- 2. La música municipal-- 3. La música teatral.- 4. La identidad musical del Corpus en Sevilla.- 5. Conclusiones.- 6. Bibliografía citada

\footnotetext{
${ }^{1}$ Abreviaturas utilizadas: $\mathrm{AC}=$ Actas Capitulares; $\mathrm{ACS}=$ Archivo de la Catedral de Sevilla; AGAS = Archivo General del Arzobispado de Sevilla; AMS = Archivo Municipal de Sevilla; doc.$=$ documento; ed. $=$ editor; $\mathrm{f} .=$ folio; $\mathrm{ff} .=$ folios; fab. $=$ fábrica; lib. $=$ libro; $\mathrm{p} .=$ página; pp. = páginas; $\mathrm{R}=$ rollo; sec. $=$ sección .
} 
El paisaje sonoro es un concepto interdisciplinar procedente de la Nueva Historia Cultural, que desde los años 80 se desarrolla en el ámbito anglosajón y que ha sido aplicado a la historia de la música en España por algunos eminentes musicólogos en ámbitos urbanos históricos concretos e incluso a nivel de ciudades, con una perspectiva más globalizadora ${ }^{2}$. En el caso de Sevilla han sido pocos y recientes los acercamientos a la realidad musical histórica desde ese punto de vista ${ }^{3}$. Para el período medieval no contamos con modelos, ni siquiera en referencia a la fase más tardía y próxima a la Modernidad. Hasta el momento, todo lo más se pueden encontrar datos en monografías consagradas a instituciones hispalenses concretas, la mayoría encuadradas cronológicamente en el Renacimiento o el Barroco ${ }^{4}$. No se ha realizado una imbricación de todas esas facetas en una visión global que recree el clima musical urbano, a diferencia del desarrollo de la musicología en la órbita anglosajona ${ }^{5}$.

No obstante permanecen cuestiones sin responder no sólo sobre las estructuras musicales de la Modernidad en Sevilla, sino también sobre sus raíces medievales. El estudio de los orígenes de los elementos que tendrán su máximo desarrollo en la civilización del Renacimiento y la del Barroco ofrece interés en la medida en que contribuye a la determinar la cronología y el grado de continuidad o ruptura entre Edad Media y Modernidad. Las conclusiones afectan ante todo a la historia de la música, que no ha sido muy estudiada en el caso de Sevilla en períodos anteriores al del maestro Francisco Guerrero, pero repercuten en la Historia general en tanto que el desarrollo del paisaje sonoro depende íntimamente del contexto económico, social, político y cultural.

El objetivo de este artículo es el rastreo documental -a través de archivos, relaciones narrativas y bibliografía- de los orígenes de las estructuras musicales en cada una de las instituciones que en pleno Renacimiento constituirían los principales agentes de la vida musical de la ciudad, así como los contextos más importantes en los que su música desempeñaba una función pública. En otras palabras, se trata de investigar la gestación del esplendor por el que se caracteriza el Siglo de Oro musical en Sevilla. La festividad del Corpus Christi ha sido escogida, como cúspide de la vida ceremonial urbana, para estudiar la cooperación de los elementos musicales de la ciudad y la atmósfera musical que crearon juntos. Su confrontación con un modelo civil como la entrada real, que se estaba conformando simultáneamente, resulta

\footnotetext{
${ }^{2}$ Marín 2002; Ramos López 1994; Bombi, Carreras, Marín 2005; García Fraile 2000.

${ }^{3}$ Ruiz Jiménez 2010; Bejarano 2010, 2013a, 2013 b.

${ }^{4}$ Las cuales configuran la bibliografía de este artículo.

${ }^{5}$ Ostrem, Petersen 2008; Peters 1997, 2000, 2005; Sherr 1998; Strohm 1990; McGee 2009; Kreitner 1990, 1995; Knighton, Morte 1999.
} 
obligada para valorar la peculiaridad musical del Corpus y su influencia. La exposición ha sido estructurada en clientes, a saber, la catedral, el concejo y las manifestaciones teatrales.

Sobre las fiestas en Sevilla durante la Edad Media apenas tenemos noticias, y en cualquier caso no suelen ser musicales ${ }^{6}$. Se conservan listas de gastos en los documentos municipales referentes a reparto de comida y bebida y a la organización de eventos deportivos, en fiestas de todos los tipos, desde el recibimiento del pendón de la ciudad victorioso hasta el nacimiento de un infante ${ }^{7}$. Las celebraciones predominantes eran las religiosas, en liturgias solemnes en los templos, aunque los caballeros hacían justas y torneos y el pueblo sortijas y cucañas a las orillas del río. En el siglo XV comenzaron a desbordar los recintos cerrados. La participación masiva del pueblo llevó a festejos callejeros sin detrimento de las funciones litúrgicas en iglesias.

Precisamente, si hay alguna fiesta que nos suministra los más tempranos datos sobre la participación de la música en el aparato ceremonial urbano, ésa es la del Corpus. Se celebraba en Sevilla, como en otras ciudades importantes castellanas, desde época alfonsina. Por razones religiosas y escriturarias, se exhortaba a tocar las campanas y a hacer resonar las trompetas, coros e instrumentos, exteriorizando el júbilo con todos los recursos sonoros $^{8}$. La primera referencia escrita a una procesión catedralicia en Sevilla data de 1363 (lo cual probablemente aluda a una tradición con raíces más largas), aunque la procesión cívica no se documenta formalmente hasta 1400. Los Papeles de Mayordomazgo del concejo municipal registran pagos a músicos - no nos consta de qué naturaleza- para el Corpus desde 1400, y este testimonio a su vez es la primera muestra administrativa de que el Corpus se celebraba en Sevilla, ya que en la Crónica de Alfonso Onceno, en una visita real a Sevilla, se describe que en el siglo XIV en el Corpus salían danzas de hombres y mujeres llevando trompetas y trompas ${ }^{9}$. Complementariamente, las actas capitulares catedralicias y los libros de fábrica correspondientes nos desvelan la dimensión económica de la fiesta, permitiendo seguir su evolución hasta la gran eclosión de la Modernidad. Abordemos cuáles eran las aportaciones musicales de cada uno de los estamentos de la ciudad a esta manifestación cívico-religiosa tan idiosincrática de la sociedad del Antiguo Régimen.

\footnotetext{
${ }^{6}$ Sánchez Herrero 1989; Ladero 2004; Pérez González 2006.

${ }^{7}$ Romero 1991,pp. 135-138. Gestoso 1993, p. 196.

${ }^{8}$ Campa 1999; 2000,pp. 54-58.

${ }^{9}$ Brooks 1988, p. 56.
} 


\section{LA MÚSICA ECLESIÁSTICA}

A lo largo del siglo XV en la procesión del Corpus sevillana el Arca del Santísimo iba rodeada de músicos, constituyendo la culminación del desfile y el polo de atracción sonora: delante de ella iban 12 mozos de coro portando hachones, 4 ancianos vestidos de profetas tañendo instrumentos, 27 cantores, 6 vestidos de ángeles que tocaban instrumentos, 8 mozos cantores con jubones y guirnaldas en la cabeza y 16 hombres cantando (probablemente la capilla de la catedral, con dos órganos portativos $)^{10}$. Por lo tanto, el paisaje sonoro en torno al Santísimo Sacramento estaba poblado de voces cantoras de jóvenes y adultos con acompañamiento de órganos por un lado, e instrumentos tocados por figuras teatrales (profetas, ángeles). La música en este caso parece desempeñar funciones que van desde la creación de una atmósfera trascendente en presencia del Sacramento con el objeto de despertar la devoción, al máximo homenaje musical al destinatario de la ceremonia.

Este blindaje musical que protege y eleva al Santísimo como un escudo tuvo que tener también efectos sacralizadores, por la naturaleza de sus intérpretes y de su repertorio. No olvidemos que algunos de ellos se disfrazan de figuras celestiales. Esta conjunción de niños y hombres y de voces e instrumentos es propia de una capilla musical. Parece que era el personal de la catedral de Sevilla el que se ocupaba de esta tarea, no sólo por los efectivos de los que disponía sino también porque el Arca pertenecía a la Iglesia y era ella la que la custodiaba durante la procesión.

La implicación musical de la catedral hispalense en la procesión del Corpus viene documentada en sus archivos. Las más antiguas disposiciones para pagar a los músicos adultos (al margen de los niños cantorcillos) que intervinieron en el Corpus sevillano datan de 1435 y están recogidas en las actas capitulares catedralicias. Nos dan indicios no sólo sobre qué necesidades musicales tenía la procesión, sino también sobre cómo se recompensaba a los profesionales por aquel trabajo en concreto. Desde los orígenes se habla de cantores, mozos de coro y órganos portativos, probablemente junto al Arca del Santísimo, que debían de interpretar música de carácter eclesiástico: en 1435 la catedral dio a 14 cantores que fueron en la procesión 140 mrs.; a 7 mozos que fueron cantando y a 4 que llevaron los órganos e uno que entonó $60 \mathrm{mrs}$.; a los que tañeron los órganos ${ }^{11}$.

Los dos registros sonoros, esto es, las voces blancas angelicales y los órganos, nos remiten directamente a la Iglesia y a la corte celestial que

\footnotetext{
${ }^{10}$ Sánchez Arjona 1898, p. 3; Gestoso 1993, pp. 93-94.

${ }^{11}$ Sentaurens 1984, vol. I, p. 72.
} 
ésta quería representar. Todo lo que rodease al Santísimo Sacramento debía revestir visos de Gloria, para alimentar la reverencia de los fieles, abrumados por la atmósfera de recogimiento y santidad. El órgano portátil, instrumento recurrente en las procesiones, aparece desde 1300 en las representaciones artísticas.

Para comprender la posición preeminente que detentaba la catedral en la faceta musical de la procesión del Corpus, debemos conocer cuán sólida era la capilla con la que contaba, auténtico polo de actividad musical en la ciudad. Ya desde tiempos de don Remondo a mediados del siglo XIII, la catedral de Sevilla en la Baja Edad Media mantenía entre su personal subalterno a varias figuras relacionadas con la música que tendrían continuidad durante toda la Edad Moderna ${ }^{12}$.

La primera es la corporación de clérigos de la veintena, cuyo número se fijó en veinte a lo largo de la Baja Edad Media y que asumían las funciones corales de los canónigos. Desde los orígenes en el estatuto de 1261 ya se habla de clérigos de coro no beneficiados. Cobraban poco por la vigésima parte de esa ración, por lo que se dedicaban a otras ocupaciones simultáneas en el ámbito catedralicio, como capellanías y sacristías. A fines del Medievo percibían cinco reales por semana (170 mrs.). Eran seleccionados por el sochantre (delegado del chantre) precisamente por sus cualidades como cantores ${ }^{13}$. Al frente de ellos en el coro encontramos al sochantre desde 1419 al menos; con anterioridad aparece mencionado el chantre o capiscol ${ }^{14}$. Con el tiempo, sus actividades musicales descienden en favor de las de sirvientes o mozos de coro quienes las asumen, de los que surgirían los niños cantores o seises con el tiempo, que cobraban 1.200 mrs. anuales, la mitad de la fábrica y la mitad de la mesa capitular ${ }^{15}$. En 1458 en los libros de mayordomía de la catedral aparecen listas de trece cantores que cobran 20 mrs. por pitanzas en el mes de junio, presumiblemente por su trabajo extraordinario en la fiesta del Corpus. Se trata de los cantores veinteneros: los miembros del coro que cantan música gregoriana o canto llano. No aparece ninguna clasificación de voces ni jerarquía aparente entre ellos. Junto a ellos, son retribuidos los dos tañedores de órgano anónimos con el mismo salario por la fiesta del Corpus, y a los mozos de coro $10 \mathrm{mrs}^{16}$. Éste era el equipo que se encargaba de la música litúrgica antes de que se desarrollara la capilla musical y el canto de órgano o polifónico, con la espectacular ampliación de la biblioteca de polifonía a partir de

${ }^{12}$ Ruiz Jiménez 2010, p. 192.

${ }^{13}$ Sánchez Herrero 1992, p. 143.

${ }^{14}$ Desde los estatutos de don Remondo de 1261, según Ortiz de Zúñiga 1988, vol. I, p. 239.

${ }^{15}$ Pérez-Embid 1977, pp. 176-177.

${ }^{16}$ ACS, Sec. IV, Fab., lib. de Mayordomía 8, ff. 17r-18v. 
$1553^{17}$. En la Edad Moderna, sin embargo, las funciones de los veinteneros no perderán relevancia, puesto que siguieron encargándose de interpretar un repertorio tradicional que continuó gozando de vigencia en el aparato litúrgico, además de ser demandado por particulares en contexto fúnebre y contribuir, en ocasiones, a reforzar con sus voces la polifonía de la capilla de música ${ }^{18}$.

También hay constancia de los tañedores de órgano ${ }^{19}$. Desde el siglo $\mathrm{X}$ se utilizan órganos para las festividades importantes en la iglesia, aunque hasta el siglo XIV no se ubicaron en tribunas en las iglesias ${ }^{20}$. Ya en 1363 las fiestas solemnes a los santos, de dotación privada, conllevaban el uso de órganos $^{21}$. Desde 1408 al menos hay dos organistas en la catedral ${ }^{22}$. En 1479 encontramos dos órganos nuevos en el altar, uno en el Sagrario y otro en la capilla de la Antigua, para sustituir a los antiguos ${ }^{23}$. Un organista servía para el culto diario, para el cual no era necesario ser muy virtuoso, pues consistía en acompañar la salmodia y rellenar algún hueco, y otro para las celebraciones extraordinarias que disponía de grandes tramos como solista. El primer organista era un religioso y recibía media ración y silla alta en el coro; el segundo podía ser laico ${ }^{24}$.

En cuanto a su status económico, aparecen libramientos de $35 \mathrm{mrs}$. a tañedores anónimos por servicios puntuales desde 1458, que tocan y entonan los órganos pequeños en la procesión de agosto, además de 10 mrs. pagados a cada uno de los dos individuos que los portan a cuestas ${ }^{25}$. En 1462, el organista de la Antigua cobró $200 \mathrm{mrs}{ }^{26}$. En 1481 los dos organistas sustitutos fueron nombrados oficialmente con un salario de $5.000 \mathrm{mrs}$. al año cada uno ${ }^{27}$. En 1495 Juan Bernal como tañedor cobró 30 mrs. por los maitines de cada una de las fiestas siguientes: la Circuncisión, la Epifanía, la Candelaria, Nuestra Señora, la Resurrección, la Anunciación, la Ascensión, Pentecostés, la Trinidad, Corpus, San Juan, la Visitación y San Pedro y San Pablo, Santiago, Santa Ana, Santa María de las Nieves, la Trasfiguración, Nuestra Señora de Agosto,

\footnotetext{
${ }^{17}$ Ruiz Jiménez 2007, pp. 143-204; Álvarez Márquez 1992, pp. 78-116, 130-163.

${ }^{18}$ ACS, Sec. VIII, Varios, capítulo 1, Capellanes de coro. Bejarano 2013a, pp. 127, 134-135.

${ }^{19}$ Pérez-Embid 1977, p. 177.

${ }^{20}$ Remnant 2002, pp. 99-100; Williams 1993, p. 5.

${ }^{21}$ Ruiz Jiménez 2014, p. 61.

${ }^{22}$ Ruiz Jiménez 2010, p. 206.

${ }^{23}$ Ayarra Jarne 1978, p. 25.

${ }^{24}$ Ayarra Jarne 1976, p. 16.

${ }^{25}$ ACS, Sec. IV, Fab., lib. de Mayordomía 8, f. 21r.

${ }^{26}$ ACS, Sec. IV, Fab., lib. de Mayordomía 9, f. 38r.

${ }^{27}$ ACS, Sec. I, AC, lib. 2, f. 55r, 15 de septiembre de 1480; lib. 3, f. 58r, 12 de noviembre de 1481. Apud. Stevenson 1985. Todas las citas que en adelante se refieran a la sección I del ACS (AC) se pueden encontrar en esta compilación documental de Robert Stevenson.
} 
Todos los Santos, Nuestra Señora y Navidad ${ }^{28}$. Desde 1507, el organista titular gozó de media ración en dinero y especie en la catedral de Sevilla ${ }^{29}$.

A finales del siglo XV empezamos a conocer los nombres de los organistas titulares, por las actas capitulares:

\begin{tabular}{|c|c|c|}
\hline & ORGANISTA TITULAR & ORGANISTAS SUSTITUTOS \\
\hline 1480 & Álvaro de Zamora & Luis de Astorga y Bernal \\
\hline 1481 & Álvaro de Zamora & Luis de Astorga y Bernal $^{30}$ \\
\hline 1482 & Álvaro de Zamora & Bernal y Cristóbal $^{31}$ \\
\hline 1485 & Álvaro de Zamora & Cristóbal y Francisco Becerra $^{32}$ \\
\hline 1507 & Francisco Becerra & Francisco de Troya, clérigo $^{33}$ \\
\hline $1507-1540$ & Diego Hernández & \\
\hline $1540-1572$ & Pedro de Villada y Alarcón & Gerónimo Núñez $^{35}$ \\
\hline
\end{tabular}

Tabla 1. Organistas de la catedral de Sevilla, 1480-1572

En la Edad Moderna, la figura del organista tendrá plena continuidad y pasará de actuar como un mero soporte armónico para los cantores a convertirse en la indispensable guardiana y encarnación de la música eclesiástica, sustituto natural del maestro de capilla ${ }^{36}$. En 1606 se definió por escrito qué competía a cada uno de los dos organistas ${ }^{37}$. Su talento musical se desarrollaría ampliamente en las siestas ${ }^{38}$. Fueron puestos muy estables que los organistas ocupaban durante largo tiempo ${ }^{39}$. En el siglo XVII el salario se incrementó en casi el triple en dinero, aunque en especie se le redujera ${ }^{40}$.

${ }^{28}$ ACS, Sec. IV, Fab., lib. de Mayordomía 18, ff. 41v-47v.

${ }^{29}$ Cárdenas 1987, p. 23.

${ }^{30}$ ACS, Sec. I, AC, lib. 2, f. 55r, 15 de septiembre de 1480; lib. 3, f. 58r, 12 de noviembre de 1481 .

${ }^{31}$ ACS, Sec. I, AC, lib. 3, f. 116r, 2 de octubre de 1482.

${ }^{32}$ Este último vino a sustituir a Bernal mientras éste estaba enfermo durante la pestilencia de 1485. Ibidem, f. 24r, 13 de mayo de 1485.

${ }^{33}$ ACS, Sec. I, AC, lib. 3b, f. 230v, 7 de junio de 1507.

${ }^{34}$ ACS, Sec. I, AC, lib. 3b, f. 233, 30 de junio de 1507.

${ }^{35}$ ACS, Sec. I, AC, lib. 14, f. 71v, 9 de diciembre de 1536.

${ }^{36}$ Edler 1983, p. 63.

${ }^{37}$ ACS, Sec. IV, Fab., lib. de salarios 324, f. 78v.

${ }^{38}$ García Fraile 2002, pp. 375-436.

${ }^{39}$ Bejarano 2013a, p. 194.

${ }^{40}$ ACS, Sec. IV, Fab., lib. 324, f. 78v. 
A partir de 1462 ya conocemos algunos nombres de personas que se encargaban de mantener los órganos de la catedral:

\begin{tabular}{|c|c|c|}
\hline FECHA & AFINACIÓN & REPARACIÓN Y MANTENIMIENTO \\
\hline 1458 & 2 entonadores $(700 \mathrm{mrs} .)^{41}$ & \\
\hline 1462 & Alfonso López, clérigo $(800 \mathrm{mrs} .)^{42}$ & Alfonso López, clérigo $(3.000 \mathrm{mrs} .)^{43}$ \\
\hline 1464 & $\begin{array}{l}\text { Juan Rodríguez (20 } \\
\text { Alfonso López, clérig }\end{array}$ & $\begin{array}{l}0 \text { mrs.) en marzo } \\
\text { o (510 mrs.) en abril }\end{array}$ \\
\hline 1478 & Un entonador a contratar ${ }^{46}$ & Fray Juan (por tiempo indefinido) ${ }^{47}$ \\
\hline 1495 & \multicolumn{2}{|c|}{ Maestro Juan (un cahíz de trigo) ${ }^{48}$} \\
\hline 1507 & \multicolumn{2}{|c|}{ Bernal de Pastrana, organero (3.000 mrs. $)^{49}$} \\
\hline 1508 & \multicolumn{2}{|c|}{ Bernal de Pastrana, organero $(3.000 \mathrm{mrs} .)^{50}$} \\
\hline 1511 & \multicolumn{2}{|c|}{ Diego Fernández, racionero (un cahíz de trigo) ${ }^{51}$} \\
\hline
\end{tabular}

Tabla 2. Personal de mantenimiento del órgano en la catedral de Sevilla, 1458-1511

En 1504 se encargan unos fuelles nuevos para los órganos del altar mayor, puesto que su mantenimiento, al tratarse del instrumento musical más utilizado en la liturgia, exige un gasto continuo ${ }^{52}$. En la Edad Moderna, la figura del organero de la catedral se institucionaliza, representándola su titular durante largos períodos de tiempo y a partir del siglo XVII con salario fijo.

También se conocen los nombres de quienes llevan los órganos portativos en la procesión del Corpus en el siglo XV, y que perciben $25 \mathrm{mrs}$. por ello. En la Edad Moderna esta figura siguió teniendo tanta relevancia o más, dada la multiplicación de procesiones y actos. Conocemos algunos de sus nombres y sabemos que recibían como mínimo un real (34 mrs.) por procesión, aunque los que tenían un salario anual asignado podía llegar hasta los $8.500 \mathrm{mrs}^{53}$.

\footnotetext{
${ }^{41}$ ACS, Sec. IV, Fab., lib. de Mayordomía 8, ff. 29v-30r.

${ }^{42}$ ACS, Sec. IV, Fab., lib. de Mayordomía 9, f. 31r.

${ }^{43}$ ACS, Sec. IV, Fab., lib. de Mayordomía 9, f. 31r.

${ }^{44}$ ACS, Sec. IV, Fab., lib. de Mayordomía 10, f. 21r.

${ }^{45}$ ACS, Sec. IV, Fab., lib. de Mayordomía 10, f. 23r.

${ }^{46}$ ACS, Sec. I, AC, lib. 1, f. 10v, 25 de febrero de 1478.

${ }^{47}$ ACS, Sec. I, AC, lib. 2, f. 12r, 12 de mayo de 1479.

${ }^{48}$ ACS, Sec. IV, Fab., lib. de Mayordomía 18, f. 3v.

${ }^{49}$ ACS, Sec. I, AC, lib. 5, f. 252v, 10 de noviembre de 1507.

${ }^{50}$ ACS, Sec. I, AC, lib. 6, f. 41v, 19 de julio de 1508.

${ }^{51}$ ACS, Sec. IV, Fab., lib. de Mayordomía 27, f. 3 r.

${ }^{52}$ ACS, Sec. I, AC, lib. 4, f. 60v, 8; f. 62v, 19 de enero de 1504.

${ }^{53}$ Bejarano 2013a, p. 193.
} 
La figura del maestro de capilla aparece en la documentación en 1439, cuando el papa Eugenio IV concedió la bula de erección en que se especifica que el maestro de capilla habría de ser un maestro de gramática y canto que se ocupara de los seises. No se menciona la labor compositiva tan temprano ${ }^{54}$. En el Siglo de Oro de la polifonía española, el maestro tenía la responsabilidad artística en una capilla musical, pero en su origen medieval, era el primer cantor de la capilla ${ }^{55}$. El primer maestro de capilla identificado en las actas capitulares fue Alonso de Alba en 1503, al cual se le facilitó la vivienda detrás del consistorio. Se sabe que éste pidió un adelanto del sueldo en dicho año ${ }^{56}$. Al año siguiente moría, siendo sustituido temporalmente por el sochantre Andrés de Ojeda ${ }^{57}$. Gracias a la almoneda de sus bienes, podemos saber dos importantes cuestiones: que en la catedral de Sevilla ya se practicaba el canto de órgano y que los maestros de capilla poseían sus propios libros de canto $^{58}$. Su sucesor permanente fue Pedro de Escobar entre 1507 y 1510, quien también tomó préstamos del cabildo ${ }^{59}$. Ya en la Edad Moderna, las funciones compositivas del maestro de capilla se fueron haciendo más exigentes por la multiplicación de festividades que necesitaban repertorio inédito; en cambio la labor docente fue delegada a otra figura especializada.

Los niños cantores en la catedral de Sevilla fueron llamados mozos, muchachos o cantorcillos durante el siglo $\mathrm{XV}$, y formaban un grupo de entre cuatro y diez, normalmente seis. Se documenta a los mozos de coro desde la fundación de la catedral de Sevilla a mediados del siglo XIII ${ }^{60}$, pero no consta su carácter musical hasta 1439, en que el papa Eugenio IV concedió la bula Ad exequendum sobre el magisterio de los seis niños cantorcicos de Sevilla ${ }^{61}$. En la procesión del Corpus se los menciona desde $1434^{62}$, pero siempre cantando o tañendo, vestidos de ángeles con alas doradas y guirnaldas de flores, y representaron este papel hasta $1539^{63}$. También participaban en otras celebraciones del calendario litúrgico de carácter teatral y vestidos de ángeles ${ }^{64}$. Las funciones de los cantorcillos estaban relacionadas con el canto, llano durante la Edad Media y de órgano posteriormente. Intervenían musicalmente

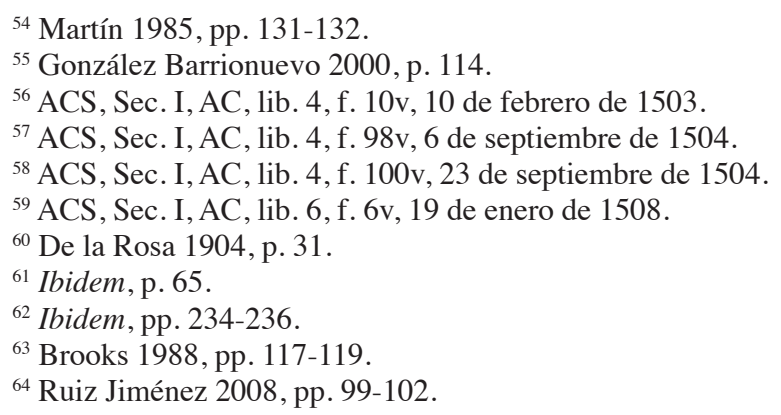


en algunos versos de canto llano del oficio divino, del de difuntos, también en algunos cantos del Ordinario de la misa ferial, así como en el gradual de la misa, en las pasiones, en la salve de los sábados y en las procesiones de capa pluvial. Por todo ello recibían una completa educación y manutención en casa del maestro, aunque en ocasiones también se les dispensaban gratificaciones y salarios en metálico. Eran seleccionados por sus cualidades musicales ${ }^{65}$. En la Edad Moderna ganaron gran protagonismo no sólo en el canto, sino también en la danza ritual. Su formación de excelencia se tornó tan importante que acabarían teniendo un maestro consagrado a su educación.

Los nombres de cantores - propiamente dichos- que conocemos son muchos. Ignoramos de cuántos miembros se componía la capilla musical al final del siglo XV, puesto que los nombres de los cantores sólo aparecen en las actas capitulares cuando es necesario destacar alguna información concreta que se refiera a ellos. El canto polifónico se interpretaba en la catedral de Sevilla, al menos para dotaciones privadas, al menos desde la década de los 20 del siglo $\mathrm{XV}^{66}$, y la intervención de cantores profesionales (probablemente polifonistas) aparece contemplada en el culto fúnebre desde fines del siglo $\mathrm{XIV}^{67}$. El número parece ir ampliándose con el transcurso del siglo XV, pues en 1408 aparecen dos y en 1479 son trece los que se mencionan. Según la sección de cuentas del archivo catedralicio, en la fiesta del Corpus en 1434 suman 26 cantores (18 adultos y 8 mozos), acompañados de organistas, y también instrumentistas desde 1454, y esta cifra irá oscilando con ligeras variaciones hasta enlazar con el siglo XVI ${ }^{68}$. En 1462, encontramos como oficiales de la catedral a seis cantores cuyos salarios oscilan entre 600 y $1.000 \mathrm{mrs}^{69}$. El salario acostumbrado para ellos era de $1.200 \mathrm{mrs}$. durante las dos últimas décadas del siglo XV, la mitad de la mesa capitular y la otra mitad de la fábrica. Al comenzar el siglo XVI, asistimos a una importante renovación del cuerpo de cantores, y el salario sube a $2.000 \mathrm{mrs}$. Hay casos de salarios de $3.000 \mathrm{mrs}$. y un cahíz de trigo, cuando se combinan varios oficios catedralicios, como el de Juan Guerrero ${ }^{70}$; en cambio otros recién llegados de la cantera sólo reciben el antiguo sueldo de 1.200 mrs., como Bartolomé de Torquemada ${ }^{71}$. Además, podían recibir estipendios especiales por festividades como la del Corpus. En 1495 la catedral libró 510 mrs. para retribuir especialmente a los cantores

\footnotetext{
${ }^{65}$ González Barrionuevo 1992, pp. 41-50.

${ }^{66}$ Ruiz Jiménez 2014, p. 68.

${ }^{67}$ Ibidem, p. 79.

${ }^{68}$ Ruiz Jiménez 2010, p. 206.

${ }^{69}$ ACS, Sec. IV, Fab., lib. de Mayordomía 9, f. 38r.

${ }^{70}$ ACS, Sec. I, AC, lib. 7, f. 55v, último miércoles de agosto de 1513.

${ }^{71}$ ACS, Sec. I, AC, lib. 7, f. 67v, 14 de noviembre de 1513.
} 
con 1 real a cada uno ${ }^{72}$, lo cual por cierto arroja un cociente de casi medio centenar de músicos. Puesto que la nómina completa de individuos resultaría insuficientemente informativa, distribuyámosla en grupos según los datos de que disponemos sobre ellos:

- En primer lugar, sirvientes como Andresico, criado del deán que recibe una cantoría en 1478, y Dieguillo, criado de doña María que la recibe en la misma fecha ${ }^{73}$. Otro ejemplo es Pedro de Vargas, criado de Pedro Sánchez de Santo Domingo, y Juan de Almodóvar, criado del doctor de Almodóvar ${ }^{74}$. A la lista hay que añadir a Diego de Santo Domingo, criado del deán ${ }^{75}$. Por lo que parece, era habitual acceder a una cantoría a través del servicio a personajes destacados, al menos en el caso de la catedral de Sevilla (faltan monografías sobre las catedrales en fechas tan pretéritas). Por ejemplo, Juan Salas tuvo problemas para obtenerla en 1478 porque luego lo contradixo el doctor de Almodóvar fasta que le diesen otra cantoría para un su criado ${ }^{76}$. De hecho, hay ocasiones en que un cantor destituye a otro merced a su servicio a determinado personaje. Tal es el caso de Juan de Almodóvar, que servía al Hospital de Santa Marta, lo cual nos informa de que el puesto no era vitalicio, sino que un músico podía ser destituido por ineptitud:

En este dicho día dieron una cantoría a Juan de Almodóvar el que sirve a los padres de Santa Marta con el salario ordinario de los otros cantores, e cometieron al licenciado Pedro Ruyz de Porras que vea la copia de los cantores e que a uno de los más desútiles e se ponga en su lugar el dicho Juan Almodóvar.

- En segundo lugar, figuras de funciones no musicales de la catedral que ascienden en la escala jerárquica y reciben más funciones de las que originalmente les corresponden: capellanes y maestros de los mozos como Martín Tudela ${ }^{77}$, Francisco Valderrama ${ }^{78}$, Juan de Villafranca ${ }^{79}$, Juan Guerrero $^{80}$.

${ }^{72}$ ACS, Sec. IV, Fab., lib. de Mayordomía 18, f. 44v.

${ }^{73}$ ACS, Sec. I, AC, lib. 1, f. 13r, 9 de marzo de 1478 .

${ }^{74}$ ACS, Sec. I, AC, lib. 2, f. 10r, 14 de abril de 1479.

${ }^{75}$ ACS, Sec. I, AC, lib. 3, f. 64v, 10 de diciembre de 1481.

${ }^{76}$ ACS, Sec. I, AC, lib. 1, f. 26v, 15 de julio de 1478.

${ }^{77}$ ACS, Sec. I, AC, lib. 1, f. 2r, 5 de enero de 1478; f. 19r, 15 de mayo de 1478.

${ }^{78}$ ACS, Sec. I, AC, lib. 2, f. 10r, 7 de abril de 1479.

${ }^{79}$ ACS, Sec. I, AC, lib. 4, f. 111r, 27 de noviembre de 1504.

${ }^{80}$ ACS, Sec. I, AC, lib. 7, f. 55v, último miércoles de agosto de 1513. 
- Cantores de los que no conocemos sino su mera existencia, como Juan de Salas, Cristóbal de Salteras ${ }^{81}$, Diego de Contreras ${ }^{82}$, Diego de Tovar ${ }^{83}$, Paredes $^{84}$, Martín de Montoya ${ }^{85}$, Francisco Bernal y Francisco de Ulloa ${ }^{86}$.

- Cantores de la generación anterior, que van muriendo durante el reinado de los Reyes Católicos, como Mateos Jiménez ${ }^{87}$, Bartolomé de Ivera y Joan de Salas ${ }^{88}$.

- Cantores que proceden de la "cantera" de la propia catedral, puesto que antes han sido mozos de coro y se han formado musicalmente en ella: Gonzalo Bernal ${ }^{89}$, Rodrigo Hernández ${ }^{90}$, Bartolomé de Torquemada ${ }^{91}$.

La primera referencia documental a una clasificación de voces o especialización en el oficio de cantor aparece en 1513, en que Juan Guerrero es denominado como tenor ${ }^{92}$. Este dato se suma a todos aquellos que apuntan al dominio del repertorio polifónico. A partir de 1518, cuando aún se estaba configurando la extensa capilla que necesitaba una sede de la relevancia de Sevilla, se observa un cambio en las actas capitulares: las nuevas adquisiciones en el personal aparecen asignadas a una cuerda de voces determinada, se especifica que se trata de clérigos presbíteros, que su misión es cantar polifonía, y el salario crece de manera exponencial, pagado en tercios ${ }^{93}$. Les seguirán en 1526 un rosario de incorporaciones ${ }^{94}$.

La causa más frecuente de cese de cantor suele ser la muerte o el ascenso en la carrera musical. Es probable encontrar esta última razón en los

${ }^{81}$ ACS, Sec. I, AC, lib. 1, f. 31r, 4 de septiembre de 1478.

${ }^{82}$ ACS, Sec. I, AC, lib. 1, f. 34v, 14 de octubre de 1478.

${ }^{83}$ ACS, Sec. I, AC, lib. 2, f. 30r, 7 de enero de 1480.

${ }^{84}$ ACS, Sec. I, AC, lib. 4, f. 190v, 23 de mayo de 1488.

${ }^{85}$ ACS, Sec. I, AC, lib. 4, f. 106r, 25 de octubre de 1504.

${ }^{86}$ ACS, Sec. I, AC, lib. 4, f. 111r, 27 de noviembre de 1504.

${ }^{87}$ ACS, Sec. I, AC, lib. 2, f. 30r, 7 de enero de 1480.

${ }^{88}$ ACS, Sec. I, AC, lib. 2, f. 48r, 19 de julio de 1480.

${ }^{89}$ ACS, Sec. I, AC, lib. 2, f. 51r, 11 de agosto de 1480.

${ }^{90}$ ACS, Sec. I, AC, lib. 7, f. 37v, 9 de mayo de 1513.

${ }^{91}$ ACS, Sec. I, AC, lib. 7, f. 67v, 14 de noviembre de 1513

${ }^{92}$ ACS, Sec. I, AC, lib. 7, f. 55v, último miércoles de agosto de 1513.

${ }^{93} 12.000$ mrs. y tres cahíces de trigo para Juan de la Parra, 10.000 mrs. para Bernaldino de Navarrete. ACS, Sec. I, AC, lib. 9, f. 166v, 18 de agosto de 1518.

${ }^{94}$ Fernando Díaz, clérigo, con 4.500 mrs. y dos cahíces de trigo (ACS, Sec. I, AC, lib. 10, f. 111r, 19 de enero de 1526), Alonso de Begil con 12.000 mrs. y dos cahíces de trigo (ibidem, f. $115 \mathrm{v}, 7$ de febrero de 1526), Juan López y Gregorio Álves, clérigos, con 6.000 mrs. y un cahíz cada uno (ibidem, f. 128r, 11 de abril de 1526), Francisco Suárez tenor con 7.500 mrs. (se le añadieron 3.000 a los 4.500 que ya cobraba en 1526) (ibidem, f. 129v, 20 de abril de 1526). 
desplazamientos por la península que realizan los músicos catedralicios a lo largo de su vida. En el siglo XVI, con el desarrollo de las capillas y las catedrales, este fenómeno alcanzará su punto álgido, pero ya en el siglo XV podemos observar algunos casos: Proveyeron los señores de la cantoría que tenía Pedro de Vargas que es ydo a Salamanca a Gonçalo Bernal moço del choro ${ }^{95}$.

Llama la atención la existencia de dinastías dentro del oficio de la música: apellidos como Bernal son recurrentes, lo cual nos hace concebir esperanzas de que se tratase de parientes y de que el oficio se transmitiese familiarmente. La verdadera dimensión de este fenómeno se nos escapa porque la forma de transmisión del patronímico no es unívoca y el orden de los apellidos es alterable.

La primera noticia sobre un procedimiento justo de selección de personal acontece en 1518, en que se encarga realizar entrevistas a los tres aspirantes, que además aparecen ya especializados y desglosados en voces. Naturalmente, esto podía corresponder a una tradición anterior. Al parecer, el salario era fruto de una negociación entre institución y músicos, dependiendo de la oferta y la demanda, que en aquellos años era importante en el panorama general de la península.

Cometieron a los señores maestrescuela y Pedro Pynelo y Luis Ordóñez sus concanónigos e al racionero Diego Fernández para que fable con los cantores tiple e tenor e contrabaxo que agora quiere asentar por cantores en esta dicha santa iglesia e que sepan dellos lo que saben e las bozes que tienen e sy son menester para esta dicha santa yglesia e qué querrán de salario cada año e qué será bueno que se les dé e que de todo fagan relaçión al Cabildo ${ }^{96}$.

En definitiva, fue en el siglo XVI cuando se comenzó a clasificar las voces y a enriquecer la capilla con músicos concienzudamente seleccionados por su cualificación venidos de cualquier procedencia, lo cual es significativo de la voluntad de la catedral de Sevilla por renovar y actualizar el cuerpo de cantores de acuerdo con los parámetros de la modernidad musical y buscando la excelencia, y del carácter central que adquiría Sevilla en el panorama musical.

De instrumentistas contratados para fiestas no se tiene noticia en la Plena Edad Media, y aún no había necesidad de una capilla musical. Ya en la segunda mitad del siglo XV, los ministriles eran contratados ocasionalmente para fiestas como la Asunción, Pascua y el Corpus, no para que se integraran en la capilla musical, sino para que animaran la Roca, por ejemplo Juan Ruiz

\footnotetext{
${ }^{95}$ ACS, Sec. I, AC, lib. 2, f. 51r, 11 de agosto de 1480.

${ }^{96}$ ACS, Sec. I, AC, lib. 9, f. 163r, 9 de agosto de 1518.
} 
en 1462 obtiene 270 mrs. y a su compañero que va tañendo en la Roca doscientos sesenta mrs. y para limosna diez mrs. que son $270^{97}$. La creación de la fiesta del Corpus en el siglo XIII, la cual siempre se relacionó con instrumentos, vinculó el gozo religioso con ellos ${ }^{98}$. A veces, como en el Corpus de 1518 , consta la presencia de los ministriles porque fueron invitados a almorzar ${ }^{99}$.

Pero los ministriles no sólo aparecen en lo relativo al Corpus. En 1497 aparece la primera referencia escrita a la contratación de personal ajeno a la capilla para una celebración litúrgica, y el hallazgo es doble porque se trata concretamente de instrumentistas para celebrar la Nochebuena por 204 mrs., aunque los efectivos musicales que les acompañaban eran los cantorcillos (442 mrs.) y los cantores (475 mrs.) y todos cobraban más que los ministriles. Estos gastos se renuevan cada año entre 1497 y 1575 . A fines de la Edad Media, en el Oficio de Pastores de Navidad, la presencia de músicos y cantores ordinarios de la catedral, especialmente retribuidos por la circunstancia, subraya los lazos de la representación teatral con el ceremonial eclesiástico tradicional $^{100}$.

Además de la Navidad, las fiestas de verano también demandaban la asistencia de los instrumentistas. En 1507 hay referencias en las actas capitulares de que se contrató ministriles para la procesión de la Virgen de los Reyes el 15 de agosto. Los ministriles cobraron a posteriori y estaban agrupados al servicio del duque (no se especifica qué duque es, pero pensamos que era el de Medina Sidonia, ya que éste era quien cedía músicos por doquier en la Baja Edad Media y está documentada su nutrida corte musical) ${ }^{101}$. Ignoramos su número, pero eran más de uno y el salario conjunto fue de $1.000 \mathrm{mrs}{ }^{102}$. En 1518 se sabe que también se los contrata para dicha fiesta ${ }^{103}$.

En 1514 unos instrumentistas sirvieron en la vigilia, maitines y día de Pascua de Resurrección, obteniendo 12 ducados de oro (4.500 mrs.), aunque no sabemos la procedencia de estos ministriles ${ }^{104}$. La siguiente referencia a los ministriles en las actas capitulares se produce en 1517 y demuestra que el calendario de fiestas con música instrumental se había ampliado, diversificándose su textura sonora:

\footnotetext{
${ }^{97}$ ACS, Sec. IV, Fab., lib. de Mayordomía 9, f. 32r.

${ }^{98}$ Whitwell 1982, p. 74.

${ }^{99}$ ACS, Sec. I, AC, lib. 9, f. 141r, 2 de junio de 1518.

${ }^{100}$ Sentaurens 1984, vol. I, pp. 21, 62.

${ }^{101}$ Clare 1988, pp. 27-57; Ruiz Jiménez 2009, pp. 401-416.

${ }^{102}$ ACS, Sec. I, AC, lib. 5, f. 240v, 16 de agosto de 1507.

${ }^{103}$ ACS, Sec. I, AC, lib. 9, f. 164r, 11 de agosto de 1518.

${ }^{104}$ ACS, Sec. I, AC, lib. 7, f. 90v, 24 de abril de 1514.
} 
Mandaron al mayordomo de la fábrica que dé e pague e reparta por los menestriles altos e trompetas e atabaleros veinte ducados de oro por lo que sirvieron la bíspera del Corpus Christi al traer del santo sacramento desde el sagrario al altar mayor e el día del Corpus Christi e la octava del Corpus Christi e la bíspera de san Pedro e sant Pablo en la torre mayor e el día principal en la proçesyón e que vea lo que todos sirvieron e les pague conforme a su servicio e a la qualidad de los instrumentos ${ }^{105}$.

A su vez empieza a aparecer en las actas la fiesta de Pentecostés. En 1532, se invierten 1.282 mrs. en 6 trompetistas y 3 timbaleros, 26 docenas de fuesées y 12 de petardos, además de la presencia de 12 cantores de la capilla y 8 cantorcillos. En Pentecostés, en la fiesta del Espíritu Santo, se celebraba un castillo en el que aparecían Dios Padre, la Virgen y los doce Apóstoles. La paloma viva que representaba al Espíritu Santo era recibida por un fuego artificial y un cohete disimulados en las superestructuras de la iglesia ${ }^{106}$.

Las manifestaciones en las que intervienen los ministriles son interiores, litúrgicas y también exteriores, como las procesiones y las luminarias nocturnas en la Giralda. También intervienen en fiestas extraordinarias que no pertenecen al calendario litúrgico:

Mandaron al mayordomo de la fábrica desta santa yglesia que dé e pague diez ducados de oro a los menestriles altos e trompetas e atabaleros e tanborinos que vinieron a honrrar la cerrada del çinborio desta santa yglesia el día de san Martín e que los reparta por ellos el dicho mayordomo considerada la calidad de los instrumentos e personas ${ }^{107}$.

Se trata de instrumentos de viento y percusión, de gran proyección sonora, probablemente al servicio del cabildo municipal, entre los cuales se adivina una fuerte jerarquización reflejada en el cobro, debida tanto a la especialización (instrumental) como a la antigüiedad. Al año siguiente, en la Pascua florida, sus instrumentos estarán más especificados: sacabuches, chirimías, trompetas y atabales, aunque cobran un ducado menos que el año anterior, por lo que pensamos que serían numéricamente menos ${ }^{108}$.

El pago a los ministriles se convertirá en un motivo progresivamente más recurrente en las actas capitulares, siempre sin indicar cómo se llamaban, cuántos individuos eran (lo cual nos impide explicar las oscilaciones en

${ }^{105}$ ACS, Sec. I, AC, lib. 9, f. 40r, 1 de junio de 1517.

${ }^{106}$ Sentaurens 1984, vol. I, pp. 25-26.

${ }^{107}$ ACS, Sec. I, AC, lib. 9, f. 82r, 13 de noviembre de 1517.

${ }^{108}$ ACS, Sec. I, AC, lib. 9, f. 121r, 9 de abril de 1518. 
el volumen del pago en unos años de inflación económica y revolución del panorama musical) o de dónde procedían. La catedral debía a los grandes señores de la ciudad el préstamo de los ministriles, puesto que se siente en cierta obligación hacia ellos.

El punto de inflexión a partir del cual podemos hablar de Modernidad en la catedral de Sevilla es aquel en el que los ministriles pasan a formar parte estable de la capilla, creándose plazas para ellos ${ }^{109}$. El sistema mediante el cual se les pagaba por jornada era poco satisfactorio porque implicaba correr el riesgo de que los mejores ministriles de la ciudad fuesen contratados por otros competidores en días tan señalados como el del Corpus o el de la Asunción ${ }^{110}$. El tema comienza a debatirse en 1526, el año de la eclosión de la capilla y sus actividades, y entonces es cuando se toma la decisión definitiva:

Platicando cómo será muy honrroso en esta santa iglesia y en alavança del culto divino tener salariados e por suyos algunos menestriles altos sacabuches e chirimías para que tengan en algunas fiestas principales e procesiones que faze esta santa yglesia lo qual se podría fazer con salario honesto e tal que no fuese mucho más que lo se les da en vezes e que servirían mucho mejor y más vezes e veniendo a votos verbales e aviendo sobre ello algunos tratados determinaron e mandaron que se resciban çinco menestriles ${ }^{111}$.

Esta resolución tiene su materialización en la relación de nóminas de ese año ${ }^{112}$. Tal vez el ejemplo de la capilla real que acompañaría a Carlos V y a Isabel de Portugal en su enlace en Sevilla el 11 de marzo de $1526^{113}$ haría al cabildo sevillano apreciar sus propias carencias musicales y la necesidad que tenía de asegurarse un abastecimiento. Las consecuencias de esta determinación serán importantes para la historia de la música en la ciudad e inaugurarán un nuevo período de dinamismo ${ }^{114}$.

Ortiz de Zúñiga, cuando introduce su mención a la capilla musical dentro de lo referente al personal de la catedral en 1261, al hablar de maestro de capilla, racioneros, gruesos estipendios, instrumentistas seglares y preponderancia a nivel nacional ${ }^{115}$, está extrapolando una realidad y un juicio propios del siglo XVII que están muy lejos de responder a la Plena Edad Media.

\footnotetext{
${ }^{109}$ Kreitner 1992a, p. 536.

${ }^{110}$ Stevenson 1993, p. 170.

${ }^{111}$ ACS, Sec. I, AC, lib. 10, f. 151v, 9 de julio de 1526.

${ }^{112}$ Ruiz Jiménez 2009, p. 60.

${ }^{113}$ Gómez-Salvago 1998, passim.

${ }^{114}$ Garbayo 2002; Ruiz Jiménez 2004; Noone 1997; Llorens 1985.

${ }^{115}$ Ortiz de Zúñiga 1988, vol. I, p. 242.
} 


\section{LA MÚSICA MUNICIPAL}

En los registros de Fábrica de la catedral se pueden encontrar libranzas desde 1435 a campaneros, cantores, mozos cantorcillos, pífanos, trompetas, tañedores y portadores de órganos, ministriles altos (de viento) y bajos (de cuerda), trompetas, atabaleros, tamborinos y panderetas, principalmente en los meses de mayo y junio ${ }^{116}$. Una gama indudablemente más amplia que la de su propio personal musical. No hay duda de que el carácter cívico y festivo de la procesión del Corpus hacía que en ella no sólo tuvieran cabida las manifestaciones más solemnes y eclesiásticas, sino también las corporativas e incluso las más profanas.

Avanzando en la cronología obtenemos pruebas de música instrumental de viento y percusión que formaba parte de la procesión, probablemente con un carácter más rítmico y festivo que la anteriormente descrita: en 6 de junio de 1488, según actas capitulares catedralicias, mandaron pagar a los pífanos lo acostumbrado, pagarles de tres años acá e mandaron dar a tres trompetas que fueron en la procesión una dobla a cada una. En 1500 también hubo trompeteros, puesto que se compraron damasco y flecos para un pendón de trompeta. En 1518 se concedieron A los ministriles, altos y bajos, que vinieron a servir en las procesiones del Corpus 24 escudos de oro. En 1533 encontramos que se dieron

A los ministriles altos y trompetas y atabaleros y tamborinos y panderetas que sirvieron en la fiesta 24 ducados. (9.000 mrs.). A los dos atabaleros que sirvieron con dos partes de atabales 36 reales $(1.224 \mathrm{mrs} .)^{117}$.

Por lo que parece, poco a poco la fiesta se va enriqueciendo instrumentalmente y se va diversificando su dotación musical. No hay duda de que estas figuras, no pertenecientes a la capilla musical, fueron contratadas por la catedral ex profeso para la fiesta. Con toda probabilidad, el concejo municipal fue el principal proveedor de trompetas, atabales e incluso ministriles, puesto que los tenía en nómina, como veremos, desde mucho antes que lo hiciera la catedral en 1526. De hecho, a veces las fuentes catedralicias confiesan la procedencia de los músicos de viento y percusión que contratan, como en 1495 , por ejemplo, en que encontramos un pago de $100 \mathrm{mrs}$. a cada uno de los seis trompetas municipales, junto con los 36 mrs. que se invierten en los tamboriles, de los que sólo sabemos que eran más de uno ${ }^{118}$.

\footnotetext{
${ }^{116}$ Sentaurens 1984, vol. I, p. 72.

${ }^{117}$ Ibidem.

${ }^{118}$ ACS, Sec. IV, Fab., lib. de Mayordomía 18, f. 43v.
} 
En otras partes de España también constan préstamos entre instituciones y contratos de ministriles con motivo de la fiesta del Corpus desde 1380, aunque las cesiones de músicos no siempre se hacían de buen grado porque se trataba de una fecha con gran necesidad de sus servicios. De hecho, la representación de la sociedad que constituía la procesión general del Corpus en el siglo XV contribuyó no poco a la profesionalización de los músicos concejiles como símbolos heráldicos de la grandeza de la ciudad, como sucedió en Barcelona simultáneamente ${ }^{119}$.

El concejo de la ciudad no estaba dotado de voces cantoras, pero en cambio estaba bien nutrido de instrumentos. Contaba con un cuerpo de trompetas y atabales por un lado y con una copla de ministriles por el otro ${ }^{120}$. El número más frecuente de músicos al servicio del cabildo es de seis individuos: tres ministriles, dos trompetas y un atabalero, aunque la proporción puede variar en algunos años. Por ejemplo, en 1431 se habla de ministriles, atabalero y trompeta. Las bandas de instrumentos de viento se asocian a los organismos municipales aproximadamente desde 1350 en toda Europa. En las ciudades alemanas es donde mayor desarrollo y tradición alcanzaron ${ }^{121}$. En Montpellier, desde la segunda mitad del siglo XIV, el concejo empleó con regularidad a cinco ministriles, dos o tres trompetas y pregoneros, además de trompetas suplementarios contratados para ocasiones especiales. Estos conjuntos eran muy estables, y también existían coplas de ministriles independientes ${ }^{122}$, mostrando una situación muy similar a la de Sevilla.

De los primeros tiempos del concejo hispalense no se tiene constancia de la existencia de músicos en el cabildo, aunque sí de pregonero, que era un oficio menor ligado a la justicia ${ }^{123}$. En la Baja Edad Media, los músicos municipales tocaban en las fiestas religiosas y otros actos celebrados en la ciudad, como lo harían en la Edad Moderna, pero sobre todo aparecen relacionados con la justicia y las milicias concejiles ${ }^{124}$. La administración de justicia estaba ligada a la majestad y por tanto al sonido de la trompeta: se conserva del 5 de julio de 1402 un mandamiento de la ciudad al mayordomo Juan Martínez, armador, para que diese 300 mrs. a Juan Rodríguez, trompeta de la Justicia de esta ciudad, de su salario por el ejercicio de dicho oficio, cuando se

\footnotetext{
${ }^{119}$ Kreitner 1992b, pp. 133-167; Raventós 2006, p. 316.

${ }^{120} \mathrm{La}$ información sobre los músicos se obtiene de la serie de Mayordomazgo, en la que aparecen libramientos de nóminas.

${ }^{121}$ Polk 1987, pp. 159-186.

${ }^{122}$ Peters 2005, p. 109.

${ }^{123}$ Tenorio 1901, p. 131.

${ }^{124}$ Kirschberg, Fernández 2002, pp. 320-321.
} 
hace justicia en Sevilla ${ }^{125}$. Asimismo, trabajaban con el pregonero: cobraban en $140310 \mathrm{mrs}$. por cada uno de los pregones en que interviniesen, mostrando previamente fe del escribano público que asistiese a ellos, y se ordenó que en adelante les diese $100 \mathrm{mrs}$. por los otros pregones que hiciesen en Sevilla ${ }^{126}$. El pregonero era un oficial municipal que hacía públicas las resoluciones del gobierno o los jueces, aunque también asuntos relacionados con particulares. Según las ordenanzas había once pregoneros de los juzgados y dos pregoneros mayores, elegidos por el alcalde mayor en época de Alfonso X y por el cabildo con posterioridad. La justicia los necesitaba especialmente para hacer públicas las sentencias, llamar a testigos, iniciar los pleitos, buscar a los criminales y rematar los bienes de los condenados ${ }^{127}$. A mediados del siglo XV, el pregonero mayor de Sevilla era criado botiller del duque de Medina, obtuvo una restitución y un privilegio del rey Juan II para que en Sevilla no hubiese otro pregonero que él ${ }^{128}$. Los otros pregoneros, Bartolomé Sánchez de Galdames y Juan Alonso, se querellaron contra él en $1459^{129}$, y lograron que se le arrebatara el puesto, pero en 1460 Adán López volvía a reclamar su puesto ${ }^{130}$.

Los tambores y las trompetas están relacionados con las ceremonias militares y con la autoridad desde la Antigüedad. Los alardes eran revistas que se hacían a las tropas o milicias concejiles durante la Reconquista. Los ordinarios se producían en marzo, julio y septiembre, pero también los había extraordinarios, con motivo de campañas o de fiestas monárquicas. Tenían lugar a una hora determinada pregonada por la ciudad y su tierra, en el campo de Tablada. La revista era llevada a cabo por el alguacil mayor, los veinticuatros y los alguaciles de los veinte ${ }^{131}$. Cuando las huestes concejiles realizaban un alarde o partían para la guerra de Granada, iban acompañadas del Pendón de la ciudad y de sus servidores los músicos ${ }^{132}$. Normalmente, se cita a las trompetas y atabales en este contexto, pero en 1407 también se incluye a los ministriles ${ }^{133}$. El 4 de julio de 1483 también tenemos un caso de dos mulas alquiladas para dos chirimías que fueron acompañando al pendón sevillano hasta Granada $^{134}$. En Córdoba también hay pruebas de que el cabildo tenía como

${ }^{125}$ AMS, sec. XV, siglo XV, R-200, 5 de julio del año 1402, 41.

${ }^{126}$ AMS, sec. XV, siglo XV, R-200,12 de marzo del año 1403, 110.

${ }^{127}$ Kirschberg, Fernández 2002, pp. 319-320.

${ }^{128}$ AMS, sec. I, AC, siglo XV, 10 de diciembre de 1455, f. 72v.

${ }^{129}$ AMS, sec. I, AC, siglo XV, 28 de noviembre de 1459, f. 137r.

${ }^{130}$ AMS, sec. I, AC, siglo XV, 2 de enero de 1460 , f. 5 r.

${ }^{131}$ Tenorio 1907, p. 16.

${ }_{132}$ Navarro 2007, pp. 521-522.

${ }^{133}$ AMS, sec. XV, siglo XV, 15 de julio de 1407, 47; todos los años en adelante, sobre fechas veraniegas, hasta 1430 en que llega la documentación.

${ }^{134}$ Carriazo 1969, vol. III, pp. 524-525. 
oficiales menores a trompeteros y percusionistas para acompañar a las tropas concejiles $^{135}$.

La primera referencia que se encuentra a pagos a trompetas data del 30 de septiembre de 1385 , aunque es posible que correspondiera a una práctica más antigua: se trata de un mandamiento de la ciudad a Pedro Jiménez, mercader de paños, para que diese 8 varas de paño de Contray (Courtrai) a cada uno de los trompetas Juan Fernández y Fernán Martínez, para su vestuario, las cuales costaron $688 \mathrm{mrs} .{ }^{136}$. Al mes siguiente se les habían sumado dos trompetas más, Juan Alonso y Alonso Martínez ${ }^{137}$. Por su parte, la primera referencia que hemos encontrado de salario de ministriles data de 1400:

Que dé a Juan Fernández e a Pedro García trompetas de Sevilla e a Juan Rodríguez, Gonzalo Fernández, Esteban Sánchez y Aparicio Rodríguez menistriles de Sevilla a cada uno dellos seyscientos mrs. en dineros para ayuda de su mantenimiento y más 8 varas de paño de Contray para su vestuario que es merced de Sevilla de los mandar dar enste dicho año por el servizio que haze a Sevilla a los dichos sus oficios cada que Sevilla los a menester a estos dichos mrs. que los dé a cada uno dellos por los tercios de año ${ }^{138}$.

Durante el reinado de los Reyes Católicos, también hay libramientos registrados, aunque no sabemos si eran pagos anuales o extraordinarios. En 14761477, Gonzalo Rodríguez y Lope de Córdoba trompetas reciben el libramiento de 1.000 mrs. y ocho varas de Contray, mientras que a Juan Rodríguez, Gonzalo Fernández, Diego de Salamanca y Alonso Téllez, ministriles, se paga a cada uno 600 mrs. y ocho varas de Contray. En 1481-1482 y 1482-1483 Alfonso Rojas y Antón Romero, representantes de los trompetas y ministriles de la ciudad, obtienen del concejo 15.000 mrs. cada uno por cada año, todo ello sufragado con los bienes de propios ${ }^{139}$. En el auto capitular del lunes 14 de Julio 1477, dentro del contexto de los gastos de la estancia de los Reyes Católicos en Sevilla, a los trompetas y atabaleros se les libra $6.000 \mathrm{mrs}$. La ciudad concedió una dádiva a los oficiales del rey, y entre ellos los trompetas recibieron $4.000 \mathrm{mrs} .{ }^{140}$.

La costumbre de tener a los músicos en nómina rara vez flaqueó, seleccionándolos mediante exámenes de pericia. En 1510 encontramos una cédula de recepción de Lorenzo de Castro como trompeta por un salario de $10.000 \mathrm{mrs}$. al año, tras haber pasado una prueba de aptitud llevada a cabo por

${ }^{135}$ Edwards 1982, p. 26.

${ }^{136}$ AMS, sec. XV, siglo XIV, R-198, 69.

${ }^{137}$ Ibidem, 74.

${ }^{138}$ AMS, sec. XV, siglo XIV, R-199, 32.

${ }^{139}$ AMS, sec. XV, nómina de las quitaciones de los años citados.

${ }^{140}$ Gestoso 1891, pp. 48-50. 
el alguacil mayor. Existían otros tres trompetas que ya estaban al servicio de la ciudad, lo cual completa el número habitual que habría en la Edad Moderna y ya provenía de la Edad Media.

Cédula que hizo Sevilla a Lorenço de Castro de le reçebir por trompeta. Señores contadores desta ciudad vuestra merced de pagar la dicha ciudad cometió al señor don Alonso de Guzmán alguacil mayor desta ciudad pagase ynformase de un trompeta para que con los otros tres que al presente la ciudad tiene le sirviesen con otra tanta quitación e salario de diez mill mrs. como se da a cada uno de los otros trompetas en cada un año e oy de la fecha desta el dicho señor don Alonso me embió su cédula por la qual dize que vido e le amiró su abilidad de Lorenço de Castro e ques buen oficial por tanto que lo mandase asentar en los libros del Cabildo de la dicha ciudad por trompeta della (...) fecha a treze días del mes de mayo de mill e quinientos e diez años ${ }^{141}$.

La transmisión del cargo se realizaba entre ellos probablemente por arrendamiento. En 1435, el trompeta Juan de Santa María solicitó renunciar a su oficio por razones de edad, y traspasarlo a Juan Alfonso, $a$ quien debía muchos favores, porque si no fuera él su sucesor, no renunciaría $^{142}$. El documento de la concesión del oficio de ministril de 1446 a Gonzalo Fernández por muerte de Pedro Rodríguez, su antecesor, no menciona cómo fue seleccionado ${ }^{143}$.

Del cabildo recibían los instrumentos que tañían, como se observa en la cita siguiente, y también más frecuentemente el vestuario ceremonial o uniforme de trabajo:

Por ciudad de Sevilla fecha 11 días de otubre de 1400 años mandato a Alfonso Pérez de Godoy 24 mayordomo de Sevilla que, de los mrs. que se an benido de las rentas y propios del concejo este año de su mayordomazgo, que compre una trompeta e que la dé a Luisejo para tañer ${ }^{144}$.

En 1417, el músico Aparicio Fernández, recibió 150 mrs. del concejo para comprarse una trompeta. Este hombre también ejercía como verdugo, confirmándonos que, desde los primeros tiempos, el de trompeta era un oficio a tiempo parcial y estaba en cierta forma relacionado con la justicia ${ }^{145}$.

${ }^{141}$ AMS, sec. XV, siglo XVI, R-1666, f. 18r.

${ }^{142}$ AMS, sec. I, AC, 4 de marzo de 1435, f. 40r.

${ }^{143}$ Kirschberg, Fernández 2002, p. 320. AMS, sec. XV, 1445-1446; 1446, junio, 8.

${ }^{144}$ AMS, sec. XV, siglo XIV, R-199, 39.

${ }^{145}$ AMS, Sec. XV, siglo XV, 9 de mayo de 1418. Collantes 1980, p. 27. 
La documentación relativa a ellos casi siempre vino al hilo de las libranzas anuales para comprar paño de Courtrai a los trompetas, ministriles, atabaleros y porteros de los contadores, para vestirlos ceremonialmente. Su función heráldica al servicio del pendón de la ciudad es la que más se refleja en las fuentes de contabilidad. Por ejemplo, en 1420 se pagaron $5.040 \mathrm{mrs}$. para vestuario nuevo ${ }^{146}$, en $14254.430 \mathrm{mrs}^{147}$, en 1426 fueron $4.200 \mathrm{mrs}$. para su vestuario y 897 para los pendones ${ }^{148}$. En 1431 se explica algo sobre el motivo de estas renovaciones de vestuario: se hacían pendones nuevos para las trompetas y paños para cubrir las albardas de las bestias que portaban los atabales y compraron jacas o rocines para los ministriles, el atabalero y un trompeta que acompañarían al rey a tierra de moros portando el pendón ${ }^{149}$. Esta tradición enlazaría con la guerra de Granada a fines de siglo: para la toma de Ronda en 1485, vestuario y pendones costaron $1.421 \mathrm{mrs} .{ }^{150}$.

Gracias a estas libranzas hemos podido conocer los nombres y salarios de algunos elencos y ver el ritmo al que se renovaban:

\begin{tabular}{|c|c|c|}
\hline & $1425^{151}$ & $1428^{152}$ \\
\hline Trompetas & $\begin{array}{l}\text { Aparicio Fernández } \\
\text { Francisco Gómez }\end{array}$ & $\begin{array}{l}\text { Gonzalo Ramírez } \\
\text { Juan de Santa María }\end{array}$ \\
\hline Atabalero & Juan Coque & Juan Coque \\
\hline Ministriles & & $\begin{array}{l}\text { Antonio Ruiz } \\
\text { Antón Martínez } \\
\text { Juan Ramírez }\end{array}$ \\
\hline Portero de cuentas & Martín González & \\
\hline
\end{tabular}

Tabla 3. Personal musical del concejo de Sevilla, 1425-1428

En 1428 cada uno cobraba 96 mrs. de la moneda forera ${ }^{153}$. Si se ausentaban de su puesto sin previa autorización, se les retiraba el salario: se conserva un mandamiento de 8 de agosto de 1429 al mayordomo para que diese 600 mrs. a Juan de Santa María, trompeta, para comprar una mula, y que

\footnotetext{
${ }^{146}$ AMS, Sec. XV, siglo XV, 1420, 1422, 1423. Collantes 1980, pp. 73, 116 y 140.

${ }^{147}$ AMS, Sec. XV, siglo XV, 1425. Collantes 1980, p. 178.

${ }^{148}$ AMS, Sec. XV, siglo XV, 1426. Collantes 1980, pp. 198 y 208.

${ }^{149}$ AMS, sec. XV, siglo XV, 12 de junio de 1431, 95. Collantes 1980, p. 275.

${ }^{150}$ Gestoso 1885 , pp. 25 y 35.

${ }^{151}$ AMS, Sec. XV, siglo XV, 1425. Collantes 1980, p. 178.

${ }_{152}$ AMS, Sec. XV, siglo XV, 29 de octubre de 1428. Collantes 1980, p. 231.

${ }^{153}$ AMS, Sec. XV, siglo XV, 29 de octubre de 1428. Collantes 1980, p. 231.
} 
los tomase de la quitación del trompeta Gonzalo Rodríguez, su compañero, que se había ausentado de la ciudad sin autorización ${ }^{154}$.

La mayoría de los pagos de trompetas y atabaleros vienen detallados en relación con la guerra fronteriza, lo cual nos hace pensar que se trataba de un pago extraordinario al margen del salario anual, y que constituía el más importante del año. Parece que la primordial razón de ser de estos instrumentos era su función heráldica militar. En 1431 la expedición del pendón a Granada se prolongaría por quince días y cada uno recibiría 12 mrs. diarios para su mantenimiento ${ }^{155}$. Ya en 1486 los dos trompetas que acompañaron al pendón a Granada recibían de salario anual 15.000 mrs., pero también les fue librada una ayuda de 1.000 mrs. a cada uno para reponer su montura perdida. En 1488 volvemos a encontrar libranzas en el contexto de la guerra, para las albricias que la ciudad de Sevilla hizo por Málaga, y también nóminas de varios trompetas: Juan de Alcántara, Juan de Ávila y su antecesor que cesa en el cargo por muerte. El salario anual seguía siendo de 15.000 mrs. ${ }^{156}$. En 1490 , como cada año, se envió a dos atabaleros para acompañar al pendón a la toma de Granada, con salario de $3.720 \mathrm{mrs}$. entre los dos: iban por período de treinta días y cada día cobraba cada uno dos reales (68 mrs.), para su sustento y el alquiler de su caballo ${ }^{157}$. Se pueden encontrar frecuentes referencias como éstas.

En la Edad Moderna observamos una gran continuidad institucional: aunque ya no hubo fronteras bélicas en las que tener funciones heráldicas, el fasto urbano se enriqueció en consonancia. Los músicos municipales medievales se mantuvieron durante la Alta Modernidad cobrando unas nóminas muy estables, con tendencia al alza durante el siglo XVI. Sus funciones heráldicas y representativas se mantendrán, aunque los escenarios serán mucho más festivos que militares ${ }^{158}$.

\section{LA MÚSICA TEATRAL}

Gracias a las libranzas para el convite posterior a la procesión, sabemos que en la procesión intervenían los juglares de Sevilla ${ }^{159}$. Probablemente todavía reciben este nombre en extinción porque este tipo de músicos era de raigambre medieval y por tanto tenía grandes conexiones con el mundo tea-

\footnotetext{
${ }^{154}$ AMS, sec. XV, siglo XV, 8 de agosto de 1429, 77. Collantes 1980, p. 252.

${ }^{155}$ AMS, sec. XV, siglo XV, 12 de junio de 1431, 95. Collantes 1980, p. 275.

${ }^{156}$ Carriazo 1969, vol. III, p. 723.

${ }^{157}$ Gestoso 1885 , pp. 28 y 44.

${ }_{158}$ Bejarano 2013a, pp. 221-314.

${ }^{159}$ González Caraballo 1997, p. 438.
} 
tral ${ }^{160}$. De hecho, muchos de los músicos, tanto vocales como instrumentales, aparecen situados en la plataforma de la Roca: en 1454 se libraron a los juglares que van en la Roca 260 mrs., llamados Juan Canario y su compañero, que tañían recreando la atmósfera celestial porque la Roca en la que tocaban simulaba una nube que los ángeles infantiles abría dejando mostrar a Dios Padre ${ }^{161}$.

Antes del Arca y detrás de cantores y órganos portátiles, después las reliquias de la Catedral, sobrevenía la Roca, un carro triunfal alegórico empujado por hombres, con representaciones mudas, cobijado bajo un cielo fingido con niños vestidos de ángeles y mozos de coro cantando bajo las andas. En este caso, la impresión de rompimiento de gloria se acentúa porque se oculta la fuente de tan divinos cantos. La Roca viene de Valencia, uno de los primeros lugares en celebrar la procesión del Corpus. Seguramente recitaban loas y alabanzas con el fondo musical del canto y los órganos realejos. En Valencia está atestiguado un texto y un acompañamiento musical desde 1415. En las Rocas o entremeses del Corpus medieval sevillano actuaban cuatro o cinco jóvenes de la cantoría, varios músicos de viola y laúd. También intervenían danzantes, pues en gastos registrados para una Roca de 1557, encontramos consignados 238 mrs. por unos zapatos dorados que se hicieron nuevos para un niño que ha de ir bailando con los cantorcicos ${ }^{162}$. Puesto que en su origen la Roca era poblada por los juglares, parece razonable que se consolidara una tradición de espectáculo teatral variado, muy vinculado con las imágenes celestiales en las que los niños jugarían el papel de los ángeles cantores y danzantes.

Ya a finales del siglo XV los músicos se han especializado y han dejado de denominarse por la palabra genérica de juglares. En 1497 puede que fueran sustituidos por músicos pertenecientes a una capilla musical, pues se libraron $a$ los cantores que iban en el cielo e al menestril que con ellos iba 4 reales. No obstante, en el siglo XVI se recupera y consolida la tendencia a emplear a músicos que se ajustan al tipo del juglar medieval: tocaban instrumentos de cuerda frotada. En 1517 la catedral libró a Alonso de Vargas, tañedor de vihuela de arco, e a otros tres que fueron con él en la nube 2 ducados. En 1518 a tres tañedores que fueron con sus rabeles y vihuelas de arcos, a cada uno 4 reales, y a Vargas tañedor 5 reales. En 1528 a los 4 mozos que fueron cantando en la nube 12 reales. En 1534 a cinco cantorcillos que iban cantando en la nube 15 reales $^{163}$.

\footnotetext{
${ }^{160}$ Bowles 1964, p. 258, encuentra un notable paralelismo en los instrumentos empleados en el Corpus y en los dramas litúrgicos coetáneos a nivel europeo.

${ }^{161}$ González Barrionuevo 1992, p. 101. La tramoya aérea es la más generalizada en los siglos XIV y XV, en particular la nube, en toda clase de representaciones religiosas, Ferrer 1992, pp. 307-322.

${ }^{162}$ Sentaurens 1984, vol. II, pp. 48-49.

${ }^{163}$ Ibidem, p. 74.
} 
El personal musical que poblaba las Rocas parece ser mixto. Por un lado, el papel de ángeles infantiles fue interpretado por mozos de coro de la catedral, entrenados en este tipo de interpretaciones desde sus orígenes. La alusión a los cantorcicos y a los niños vestidos de ángeles bailando es bastante elocuente. Por el otro lado, aquellos llamados juglares o tañedores de instrumentos de cuerda no formaban parte de una capilla musical, sino que procedían del otro mundo musical: el del espectáculo, el entretenimiento y el repertorio profano. Ya en la segunda mitad del siglo XVI, cuando de las representaciones teatrales del Corpus se encarguen compañías profesionales de representantes, serán los músicos especializados en teatro los que toquen a bordo de los carros ${ }^{164}$, lo cual ilustra la continuidad de la tradición.

Los grupos vocales e instrumentales en el Corpus fueron en aumento en la segunda mitad del siglo XV, cuando también se amplió el número de representaciones y personajes que participaban ${ }^{165}$. En la primera mitad del siglo XVI, las Rocas darán paso a un amplio abanico de juegos, danzas y carros desarrollados por varios gremios ${ }^{166}$, con la diversificación musical que eso significa. Cuando en plena Edad Moderna los juegos del Corpus pasen a ser responsabilidad del Cabildo municipal, el proceso de enriquecimiento musical y coreográfico llegará a su apogeo.

\section{LA IDENTIDAD MUSICAL DEL CORPUS EN SEVILLA}

Así pues, los tres estamentos representados por la música eclesiástica, concejil y popular realizaron sus propias aportaciones al paisaje musical del Corpus, en tanto que la fiesta venía a ser la cúspide del fasto público anual y la ocasión más señalada para la manifestación pública de espíritu urbano en torno a una causa devocional. La unión de las artes contribuía a una simbología común ${ }^{167}$. Los distintos cuerpos musicales, además de significar el homenaje de todos los poderes terrenales y estamentos hacia la Eucarística, atribuían connotaciones a la Custodia: mientras que la Iglesia y el mundo de la música teatral subrayaban el carácter del Sacramento como llave del cielo, el concejo hacía hincapié en su vertiente de fuente de justicia, fuerza y autoridad. Cada uno de ellos se basó en una tradición musical distinta, las cuales dentro del contexto europeo experimentaban las mismas tendencias expansivas: la Iglesia desarrollaba la institución de la capilla musical, los concejos urbanos

\footnotetext{
${ }^{164}$ Ibidem, pp. 20-61 ; Bejarano 2013c, passim.

${ }^{165}$ Gómez Muntané 2001, pp. 96-99.

${ }^{166}$ Sanz 1997, 2007; Pérez González 2003, 2005, Bejarano 2009, 2010.

${ }^{167}$ Bowles 1964, p. 251.
} 
estaban consolidando su propia personalidad musical durante la etapa bajomedieval y los músicos del espectáculo estaban en proceso de transformación de la figura del juglar a la del tañedor, cantante y danzante teatral, igualmente polifacética. La primera hizo hincapié en la especialización vocal polifónica con su versión instrumental, el órgano. El segundo se especializó en la gama instrumental de viento y percusión, instrumentos con vocación ceremonial al aire libre. El tercer grupo aportó su pericia en la simultaneidad del canto, la danza y los instrumentos de cuerda acompañantes.

¿Este clima musical era específicamente sevillano? Otras ciudades principales de la Península en la Baja Edad Media apuntan las mismas tendencias. En Toledo, desde mediados del siglo XV se documenta que la catedral pagaba en cada procesión del Corpus y de la Ascensión a grupos de tañedores y ministriles ${ }^{168}$. En las ciudades de la Corona de Aragón (Gerona, Barcelona y Valencia), los instrumentos mencionados en las procesiones del Corpus de 1380 y 1404 se refieren a juglares disfrazados de ángeles y evangelistas tañendo instrumentos de cuerda (arpa, laúd, guitarra y rabel $)^{169}$, lo cual confirma que la figura del polifacético y teatral músico juglar antecede cronológicamente a la del ministril y la capilla musical en la celebración del Corpus. En Barcelona de 1424 en adelante el concejo municipal llegaba a la misa en la catedral precedido por "juglares" tocando aerófonos de metal. La procesión también era precedida por una copla de hasta diez trompetas que eran contratadas ex profeso para todos los desplazamientos de la fiesta por parte del cabildo municipal, pues en la Baja Edad Media los concejos todavía no tienen (suficientes) trompeteros en nómina, cosa que irá corrigiéndose con el devenir del Renacimiento. Cada ciertos tramos aparecía una docena de ángeles cantores, quizá también instrumentistas: se sospecha que podrían haber habido más tomando parte en los entremeses o representaciones teatrales entre las que se les sitúa. Rodeando a la custodia iban diez ángeles cantando, que debían de ser la capilla catedralicia, otros diez tocando cordófonos (los tañedores de cuerda en Barcelona ya desde 1424 formaban una copla dirigida por un espadero, y también existían en el Corpus de Gerona y de Salamanca a fines de siglo) y 24 ancianos del Apocalipsis cantando, que debían de pertenecer a la capilla catedralicia e interpretar canto $11 a^{170}{ }^{170}$. Todo lo cual obedece a la lógica según la cual los estamentos hacen aportaciones a la procesión ${ }^{171}$. El Corpus español se diferencia del europeo en que las representaciones tea-

\footnotetext{
${ }^{168}$ Reynaud 1996, 199-200.

${ }^{169}$ Bowles 1964, pp. 257-258.

${ }^{170}$ Kreitner 1995, pp. 157-191.

${ }^{171}$ Raufast 2006b, p. 653, demuestra cómo también en la ceremonia urbana del Corpus de Barcelona en el siglo XV se produce una similar implicación de los estamentos con represen-
} 
trales no se realizan en el templo, sino que se incorporan a la procesión, con el aporte musical cuantitativo y tipológico que supone para ésta ${ }^{172}$. Áreas de influencia de Sevilla como el reino de Granada también recibirían su influjo a comienzos del siglo XVI: en la procesión del Corpus de Málaga, los seises también cantaban himnos y bailaban, junto con la intervención de cantores, órganos y clerecía ${ }^{173}$.

¿Esta atmósfera de conjunción musical en Sevilla era exclusiva del Corpus? Ya hemos mencionado que en los registros documentales de las instituciones se conservan menciones a intervenciones musicales en otras festividades, de carácter religioso y civil, pero no parece que antes de las grandes fiestas contrarreformistas existiera una contribución global como a la del Corpus en otro punto del año. La contrapartida civil de esta celebración podría ser la entrada real, siempre eventual. Puesto que estas ocasiones eran absolutamente extraordinarias, su aparato toma muchas de las liturgias del Corpus, que estaban profundamente enraizadas en la sociedad y harto ensayadas, y tenían el mismo sentido de homenaje a una instancia superior a la ciudad ${ }^{174}$.

En la Baja Edad Media se registra un despliegue ceremonial monárquico, porque la dinastía Trastámara tenía especiales necesidades de legitimarse y hacerse presente. Las entradas reales desempeñaron un papel central en la estructura ritual a causa de su eficacia, y porque el papel de la ciudad se incrementó relevantemente ${ }^{175}$. La ceremonia adquirió un alto grado de teatralización ${ }^{176}$. De hecho, la entrada real tomó elementos propios de la procesión del Corpus ${ }^{177}$. Ya en el siglo XVI la capilla musical empieza a mencionarse como tal en las fuentes narrativas: en la entrada triunfal de Fernando el Católico y Germana de Foix en 1508, una entrada triunfal renacentista propiamente dicha, la capilla musical de la catedral de Sevilla comenzaba a destacar en las relaciones: Llegó de noche a la santa Yglesia, la qual esttaba llena de Luces y perfumes de diferentes Olores, enttró en la Capilla mayor Canttando la Música, hizo oración ${ }^{178}$. Esto es, la capilla musical solemnizó la llegada del rey con todas las connotaciones de sacralización que ello conlleva. Se conoce al

tación política de la ciudad, en la que se juegan su prestigio y honor, de ahí que se produjeran conflictos.

172 Ibidem, p. 194.

${ }^{173}$ Ybáñez 1999, p. 385.

${ }^{174}$ Raufast 2008, p. 1083, afirma que en la entrada de Fernando II en 1469 en Barcelona se llevó a cabo una procesión idéntica a la del Corpus.

${ }^{175}$ Raufast 2006c, p. 299; 2008, p. 1083. El autor hace hincapié en que, en la entrada real, la ciudad desempeña un papel activo desarrollando una ritualidad propia como receptora.

${ }^{176}$ Nieto 1999, pp. 46-54; Kipling 1998, passim.

${ }^{177}$ Ferrer 1992, pp. 307-322.

${ }^{178}$ AMS, Sec. XI, papeles del conde del Águila, tomo 7, doc. 17, pp. 183-389. 
detalle esta entrada gracias a los relatos de Andrés Bernáldez en su Memoria del reinado de los Reyes Católicos, contemporáneo de ello, y Ortiz de Zúñiga en sus Anales, que no lo fue. Afortunadamente, contamos con documentación de distinta naturaleza, más económica y administrativa, con la que comparar las crónicas, labor que llevó a cabo Vicente Lleó Cañal ${ }^{179}$. Como todos los reyes, entró por la puerta Macarena no sin antes haber jurado los privilegios, recibido por los dos cabildos en procesión, con objeto de legitimarse como regente de Castilla, pero la gran novedad reside en el programa iconográfico efímero que se había dispuesto en su honor: su recorrido hasta la catedral aparecía jalonado por trece arcos triunfales de madera ricamente decorados. Para ser apreciados tuvieron que iluminarse, puesto que el rey llegó a la catedral de noche ${ }^{180}$. Este itinerario se torna una via triumphalis a la manera de los militares romanos victoriosos, una vía de penetración al corazón de la ciudad pasando por sus puntos más emblemáticos, entre los eclesiásticos y los civiles, tal como hacía la procesión del Corpus ${ }^{181}$. Gracias a ellos Sevilla sustituye su imagen medieval e islámica por otra más moderna, clásica y cristiana ${ }^{182}$. El urbanismo es una manifestación más del pensamiento utópico renacentista ${ }^{183}$, pero manteniendo la herencia medieval de la íntima vinculación entre urbanismo y fiesta: el espacio escénico medieval es la propia ciudad, de forma que el espacio teatral coincide con el real ${ }^{184}$. Aunque las fuentes no lo mencionen, es posible que, como sucedió en una entrada similar en Valladolid al año siguiente ${ }^{185}$, alguno de los arcos triunfales sirviera como plataforma a músicos y coros infantiles y polifónicos, tal como sucedía en la Roca del Corpus.

Por su parte, los esponsales de Carlos I con Isabel de Portugal se celebraron en Sevilla en 1526 por decisión tardía, casi como improvisación, aunque la visita sí se esperaba y se preparaba desde largo tiempo antes. La conocemos a través de Diego Ortiz de Zúñiga, que parece haber copiado la relación oficial que ordenó imprimir la ciudad, aunque dicha publicación no llegó a realizarse ${ }^{186}$. Fueron siete los arcos dispuestos a lo largo del mismo recorrido que realizó su abuelo Fernando. El extenso programa iconográfico,

\footnotetext{
${ }^{179}$ Lleó 1978, pp. 9-23.

${ }^{180}$ Ramos Sosa 1986, p. 174.

${ }^{181}$ En Barcelona en el siglo XV también se encuentra un absoluto paralelismo entre el itinerario de la procesión del Corpus y el de las entradas reales, como afirma Raufast 2006a, pp. 134-146; 2007, p. 105.

${ }^{182}$ El modelo de esta y otras entradas de Fernando el Católico en ciudades españolas fue la que realizó en Nápoles en 1506, Knighton, Morte 1999, pp. 127-129.

${ }^{183}$ Lleó 1979, p. 173.

${ }^{184}$ Ferrer 1992, pp. 307-322.

${ }^{185}$ Knighton, Morte 1999, pp. 147-148.

${ }^{186}$ Ramos Sosa 1986, p. 180.
} 
netamente renacentista y paganizante, es prolijamente descrito por Ortiz de Zúñiga. El último arco, ubicado en las Gradas, parece ser el más espectacular y el único con componentes musicales porque va acompañado del recibimiento del cabildo de la catedral. La procesión de recepción del cabildo eclesiástico también en esta ocasión incluía su vertiente musical, puesto que la capilla musical era uno de los tesoros que caracterizaban a la institución y contribuían a sacralizar a la monarquía:

Entró la Emperatriz (...) prosiguió su Estación hasta Calle Génova, donde llegaba la prosesión del Cavildo Eclesiástico (...) y un Coro de Niños de Coro en forma de las virtudes, cada uno con sus Ynsignias, y cantando con suave melodía la acompañaron y llevaron hasta la Capilla maior (...) Ocho días después vino el Emperador (...), y hizo el Juramento de Guardar las inmunidades de la Santa Yglesia, y luego el Coro de Niños, y la Música entonó el Te Deum laudamus y lo fueron cantando hasta la Capilla maior ${ }^{187}$.

La puerta de la catedral simbolizaba la del propio cielo, la Jerusalén celeste. De hecho, el emperador compareció con una rama de olivo en la mano sobre caballo rodado color de cielo, en mesiánica alusión a la paz que acababa de firmar con Francisco I. En este proceso de sacralización, se utiliza por segunda vez el palio en una entrada en Sevilla, pues el primero en emplearlo había sido Alfonso XI ${ }^{188}$. Pero la música de la catedral no fue la única que recibió a Carlos I. Es lógico asumir que el cabildo municipal acudiese escoltado por todos sus efectivos musicales, esto es, atabales, trompetas y chirimías, que aportaron el homenaje heráldico a la monarquía:

Llegó a la puerta de Macarena (...); y así acompañado por los lugares donde los arcos estaban, las calles ricamente ataviadas de muy ricos paños y tapicería, con mucha música de diversos instrumentos reales, llegó a la Iglesia mayor.

Asimismo, también nos remite al Corpus el recibimiento que la catedral dispensó a la emperatriz, puesto que el arco de triunfo estuvo vivificado por los mismos agentes que poblaban las Rocas:

Llegando (la procesión) a la Iglesia Mayor, las cruces con sus invenciones, y los Señores de la Iglesia vestidos con sobrepellices y capas, la salieron a recibir a la puerta del Perdón nueva, donde los Señores de la Iglesia habían mandado hacer un arco muy suntuoso con un cielo en medio, de donde salían ciertos

${ }^{187}$ AMS, Sec. XI, Papeles del conde del Águila, tomo 7, doc. 17, pp. 183-389.

${ }^{188}$ Lleó 1979, pp. 165-166. 
Ángeles, y con un corro de mozos de coro en figura de las virtudes, con suave melodía, y cada uno con su insignia, la recibieron y la acompañaron hasta la capilla antigua de nuestra Señora la Madre de Dios ${ }^{189}$.

Todo esto nos conduce a valorar la importancia del Corpus como fiesta modélica e inspiradora de ceremoniales urbanos. Aplicando a la monarquía rituales semejantes a los sacramentales, la ciudad no sólo le transfería connotaciones sacralizadoras a la realeza, no sólo negociaba su concepto de homenaje a instancias superiores, sino que a través de un determinado ceremonial con su peculiar paisaje sonoro también contribuía a afirmar su propia identidad como comunidad.

\section{CONCLUSIONES}

La representación de la sociedad que constituía la procesión general del Corpus en el siglo XV contribuyó no poco a la profesionalización de los músicos en tanto que los estamentos los necesitaban para representarse en este conjunto y contribuir a la identidad devocional de la ciudad. El Arca del Santísimo iba rodeada de músicos eclesiásticos, constituyendo la culminación del desfile y el polo de atracción de los efectivos musicales de carácter religioso (instrumentistas, organistas, mozos de coro y cantores). El otro polo de concentración musical son los castillos: músicos herederos de los juglares, tanto vocales como instrumentales y danzantes, aparecen situados en las Rocas. Por su parte, los instrumentos de viento y percusión municipales dotaban a la procesión de un carácter más rítmico y festivo. Poco a poco la fiesta se fue enriqueciendo instrumentalmente y se fue diversificando su dotación musical. Los grupos vocales e instrumentales en el Corpus fueron en aumento simultáneamente a la ampliación del número de representaciones y personajes que participaban. La importancia creciente de la música en las atracciones del Corpus fue constantemente en aumento durante la Alta Modernidad, sin que la transferencia de competencias desde los gremios hacia el concejo municipal significara el menor freno a este proceso.

No obstante, ni estos elementos musicales ni su interacción entre ellos eran privativos de la festividad del Corpus, sino que constituían un lenguaje sonoro, compartido con otras ciudades españolas, con el que la sociedad expresaba conceptos abstractos como la unión, la devoción, la solemnidad y el reconocimiento, fuera cual fuera la naturaleza de la ocasión.

${ }^{189}$ Ortiz de Zúñiga 1988, vol. III, pp. 355-356. 
Los elementos musicales que caracterizaron la civilización de la Edad Moderna en Sevilla hunden sus raíces en buena parte en la Baja Edad Media. Las tradiciones parecen remontarse a la Reconquista pero están documentadas fundamentalmente a partir del siglo XV. A través de las fuentes de diversa naturaleza podemos comprobar que las figuras relacionadas con la música tenían una vinculación institucional desde tiempos medievales, que no hizo sino asentarse en época moderna. Repartidas entre las instituciones, fueron multiplicándose, diversificándose y asentándose durante el siglo XV con gran sentido de la continuidad conforme la dotación económica de las instituciones y la visión moderna de la vida ceremonial urbana fue demandándolo. Este crecimiento de las figuras y recursos sonoros está justificado por una progresiva prosperidad económica, una sociedad que tiende a la participación en el ritual público, unas instituciones con intereses en la manifestación social de su prestigio y convencimientos (políticos o religiosos) y un marco cultural renacentista que favoreció el desarrollo de los programas iconográficos en las celebraciones. Entre la Edad Media y la Moderna fueron convirtiéndose en imprescindibles para la concepción moderna de lo ritual.

\section{BIBLIOGRAFÍA CITADA}

Álvarez Márquez, María del Carmen (1992), El mundo del libro en la iglesia catedral de Sevilla en el siglo XVI, Sevilla, Diputación Provincial de Sevilla.

Ayarra Jarne, José Enrique (1976), La música en la catedral de Sevilla, Sevilla, Caja de Ahorros.

Ayarra Jarne, José Enrique (1978), El órgano en Sevilla y su provincia, Sevilla, Obra Cultural de la Caja de Ahorros Provincial San Fernando de Sevilla.

Bejarano Pellicer, Clara (2009), El paisaje sonoro del hospital de las Cinco Llagas de Sevilla durante la Edad Moderna, "Chronica Nova" 35, pp. 223-246.

Bejarano Pellicer, Clara (2010), La música en los gremios y las cofradías de la Sevilla del Antiguo Régimen, "Archivo Hispalense" 282-284, pp. 223-245.

Bejarano Pellicer, Clara (2013a), El mercado de la música en la Sevilla del Siglo de Oro, Sevilla, Universidad de Sevilla - Fundación FocusAbengoa.

Bejarano Pellicer, Clara (2013b), "De la parte de dentro o de la parte de fuera": la capilla paralela de San Salvador de Sevilla a comienzos del siglo XVII, "Revista de Humanidades" 20, URL: http://www. 
revistadehumanidades.com/articulos/46-de-la-parte-de-dentro-o-dela-parte-de-fuera-la-capilla-paralela-de-san-salvador-de-sevilla-acomienzos-del-siglo-xvii [consulta: 12/05/2015].

Bejarano Pellicer, Clara (2013c), El oficio de representar y el oficio de la música en Sevilla entre 1575 y 1625, "Philologia Hispalensis" 27, pp. 29-54.

Bombi, Andrea; Carreras, Juan José; Marín, Miguel Ángel (2005), Música y cultura urbana en la Edad Moderna, Valencia, Universidad de Valencia.

Bowles, Edmund A. (1964), Musical Instruments in the Medieval Corpus Christi Procession, "Journal of the American Musicological Society" 17/3, pp. 251-260.

Brooks, Lynn Matluck, (1988), The dances of the procesions of Seville in Spain's Golden Age, Kassel, Reichenberger.

Campa Carmona, Ramón de la (1999), La procesión del Corpus Christi: origen y significación, "Boletín de las cofradías de Sevilla" 484, pp. 42-47.

Campa Carmona, Ramón de la (2000), Origen de la solemnidad del cuerpo y la sangre de Cristo en la Iglesia Católica, "Boletín de las Cofradías de Sevilla" 496, pp. 54-58.

Cárdenas Serván, Inmaculada (1987), El polifonista Alonso Lobo y su entorno, Santiago de Compostela, Universidad de Santiago de Compostela.

Carriazo Arroquia, Juan de Mata (1969), Historia de la guerra de Granada, en Menéndez Pidal, Ramón (dir.), Historia de España, Madrid, Espasa-Calpe, tomo XVII-1, pp. 385-914.

Clare, Lucien (1988), Le connétable, la musique et le pouvoir, "Bulletin Hispanique" 90 , pp. $27-57$.

Collantes de Terán, Francisco (1980), Inventario de los papeles del Mayordomazgo del siglo XV (1417-1431), Sevilla, Ayuntamiento de Sevilla.

Edler, Arnfried (1983), The social status of organists in Lutheran Germany from the 16th through the 19th century, en Salmen, Walter (ed.), The social status of the professional musician from the Middle Ages to the 19th century, Nueva York, Pendragon, pp. 61-94.

Edwards, John (1982), Christian Cordoba. The city and its region in the Late Middle Age, Cambridge, Cambridge University Press.

Ferrer Valls, Teresa (1992), El espectáculo profano en la Edad Media: espacio escénico y escenografía, en Beltrán, Rafael; Canet, José Luis; Sirera, Josep Lluís (eds.), Historias y ficciones: coloquio sobre la literatura del siglo $X V$, Valencia, Universidad de Valencia, pp. 307-322.

Garbayo, Javier (2002), Música instrumental y liturgia en las catedrales españolas en tiempos de Barroco, "Revista Quintana" 1, pp. 211-224.

García Fraile, Dámaso (2000), La vida musical en la Universidad de Salamanca durante el siglo XVI, "Revista de Musicología" 23/1, pp. 9-74. 
García Fraile, Dámaso (2002), Las siestas como actividad musical en las iglesias hispanas durante el Antiguo Régimen, "Nassarre" 18/1-2, pp. 375-436.

Gestoso y Pérez, José (1885), Noticia histórico-descriptiva del antiguo pendón de la ciudad de Sevilla que se conserva en su archivo Municipal, Sevilla, Gironés y Orduña.

Gestoso y Pérez, José (1891), Los Reyes Católicos en Sevilla (1477-1478), Sevilla, Revista de Tribunales.

Gestoso y Pérez, José (1993), Curiosidades antiguas sevillanas (segunda serie), Sevilla, Ayuntamiento de Sevilla.

Gómez Muntané, María del Carmen (2001), La música medieval en España, Kassel, Reichenberger.

Gómez-Salvago Sánchez, Mónica (1998), Fastos de una boda real en la Sevilla del quinientos (Estudio y documentos), Sevilla, Universidad de Sevilla.

González Barrionuevo, Herminio (1992), Los seises de Sevilla, Sevilla, Editorial Castillejo.

González Barrionuevo, Herminio (2000), Francisco Guerrero (1528-1599) vida y obra. La música en la catedral de Sevilla a finales del siglo XVI, Sevilla, Cabildo Metropolitano de la Catedral de Sevilla.

González Caraballo, José (1997), Corpus Christi en Sevilla: actores y escenario, en Campos y Fernández de Sevilla, Francisco Javier (coord.), Religiosidad popular en España. Actas del Simposium, San Lorenzo de El Escorial, Real Centro Universitario Escorial-María Cristina, vol. 2, pp. 425-437.

Gutiérrez Cordero, María del Rosario (2008), La música en la colegiata de San Salvador de Sevilla, Granada, Junta de Andalucía, Consejería de Cultura - Centro de Documentación Musical de Andalucía.

Kipling, Gordon (1998), Enter the King. Theatre, liturgy and ritual in the Medieval Civic Triumph, Oxford, Clarendon Press.

Kirschberg Schenck, Deborah; Fernández Gómez, Marcos (2002), El Concejo de Sevilla en la Edad Media (1248-1454). Organización Institucional y Fuentes Documentales I, Sevilla, Ayuntamiento de Sevilla.

Knighton, Tess; Morte, Carmen (1999), Ferdinand of Aragon's entry into Valladolid in 1513: the triumph of a Christian King, "Early Music History" 18, pp. 119-163.

Kreitner, Kenneth (1990), Music and Civic Ceremony in Late Fifteenth-Century Barcelona, Durham, Duke University (tesis doctoral).

Kreitner, Kenneth (1992a), Minstrels in Spanish Churches, 1400-1600, "Early music" 20/4, pp. 532-546.

Kreitner, Kenneth (1992b), The City Trumpeter in Late Fifteenth Century Barcelona, "Musica Disciplina" 46, pp. 133-167. 
Kreitner, Kenneth (1995), Music in the Corpus Christi Procession in Fifteenth-century Barcelona, "Early Music History" 14, pp. 153-204.

Ladero Quesada, Miguel Ángel (2004), Las fiestas en la cultura medieval, Barcelona, Areté.

Lleó Cañal, Vicente (1978), Recibimiento en Sevilla del Rey Fernando el Católico (1508), “Archivo Hispalense” 188, pp. 9-25.

Lleó Cañal, Vicente (1979), Nueva Roma: mitología y humanismo en el Renacimiento sevillano, Sevilla, Diputación Provincial de Sevilla.

Llorens Cisteró, José María (1985), Música y músicos en la Sevilla del Siglo de Oro, "Boletín de Bellas Artes" 13, pp. 115-142.

Marín, Miguel Ángel (2002), Music on the margin. Urban musical life in eighteen century Jaca (Spain), Kassel, Reichenberger.

Martín Moreno, Antonio (1985), Historia de la música andaluza, Granada, Biblioteca de la Cultura Andaluza.

McGee, Timothy J. (2009), The Ceremonial Musicians of Late Medieval Florence, Bloomington, IN, Indiana University Press.

Navarro Saínz, José María (2007), El Concejo de Sevilla en el reinado de Isabel I (1474-1504), Sevilla, Diputación de Sevilla.

Nieto Soria, José Manuel (dir.) (1999), Orígenes de la monarquía hispánica. Propaganda y legitimación (1400-1520), Madrid, Dykinson.

Noone, Michael (1997), Los ministriles en la Catedral de Toledo en la segunda mitad del siglo XVI, en Lavado, Pedro J. (ed.), Los instrumentos musicales en el siglo XVI, Ávila, Fundación Cultural Santa Teresa, pp. 125-134.

Ortiz de Zúñiga, Diego (1988), Anales eclesiásticos y seculares de la muy noble y muy leal ciudad de Sevilla, ed. José Sánchez Dubé, edición facsímil de Madrid, Imprenta Real, Juan García Infançón, 1667, Sevilla, Guadalquivir.

Ostrem, Eyolf; Petersen, Nils Holger (2008), Medieval ritual and Early Modern Music, Turnhout, Brepols.

Pérez González, Silvia María (2003), La presencia de las Cofradías en la fiesta del Corpus Christi de Sevilla a fines del siglo XV y comienzos del XVI, "Boletín de las Cofradías de Sevilla" 532, pp. 450-451.

Pérez González, Silvia María (2005), Los laicos en la Sevilla bajomedieval. Sus devociones y cofradías, Huelva, Universidad de Huelva.

Pérez González, Silvia María (2006), Los santos venerados en Sevilla en el siglo $X V$ y principios del XVI, en Vitse, Marc (coord.), Homenaje a Henri Guerreiro: la hagiografía entre historia y literatura en la España de la Edad Media y del Siglo de Oro, Madrid, Iberoamericana, pp. 985-997. Pérez-Embid, Javier (1977), El Cabildo de Sevilla en la Baja Edad Media, "Hispania sacra" 30/59-60, pp. 143-181. 
Pérez-Embid, Javier (1978/1979), La Colegiata de San Salvador de Sevilla en la Baja Edad Media (1350-1520), "Hispania Sacra" 31/61-64, pp. 180-182.

Peters, Gretchen (1997), Urban musical culture in late medieval southern France, "Early Music" 25, pp. 403-410.

Peters, Gretchen (2000), Urban minstrels in Late Medieval Southern France, "Early Music History" 19, pp. 201-235.

Peters, Gretchen (2005), Las redes sociales y profesionales de los ministriles de Montpellier, 1350-1500, en Bombi, Andrea; Carreras, Juan José; Marín, Miguel Ángel (coords.), Música y cultura urbana en la Edad Moderna, Valencia, Universidad de Valencia, pp. 107-113.

Polk, Keith (1987), Instrumental music in the urban centres of Renaissance Germany, "Early Music History" 7, pp. 159-186.

Ramos López, Pilar (1994), La música en la catedral de Granada en la primera mitad del siglo XVII: Diego de Pontac, Granada, Diputación Provincial de Granada.

Ramos Sosa, Rafael (1986), Fiestas reales sevillanas en el Imperio (15001550), Sevilla, Ayuntamiento de Sevilla.

Raufast Chico, Miguel (2006a), Itineraris processionals a la Barcelona baixmedieval, "Revista d'Etnologia de Catalunya" 29, pp. 134-146.

Raufast Chico, Miguel (2006b), "E vingueren los officis e confraries ab llurs entremeses e balls". Una aproximación al estamento artesanal en la barcelona bajomedieval, a partir del estudio de las ceremonias de entrada real, "Anuario de Estudios Medievales" 36/2, pp. 651686.

Raufast Chico, Miguel (2006c), ¿Negociar la entrada del rey? La entrada real de Juan II en Barcelona (1485), "Anuario de Estudios Medievales" 36/1, pp. 295-333.

Raufast Chico, Miguel (2007), ¿Un mismo ceremonial para dos dinastías? Las entradas reales de Martín el Humano (1397) y Fernando I (1412) en Barcelona, "En la España medieval" 30, pp. 91-130.

Raufast Chico, Miguel (2008), Ceremonia y conflicto: entradas reales en Barcelona en el contexto de la Guerra Civil catalana (1460-1473), "Anuario de Estudios Medievales" 38/2, pp. 1037-1085.

Raventós Freixa, Jordi (2006), Manifestacions musicals a Barcelona a través de la festa: les entrades reials (segles XV-XVIII), Gerona, Universidad de Gerona (tesis doctoral).

Remnant, Mary (2002), Historia de los instrumentos musicales, Barcelona, Robinbook.

Reynaud, François (1996), La Polyphonie Tolédane et son milieu. Des prémiers témoignages aux environs de 1600, París, CNRS.

ANUARIO de Estudios MEdievales, 46/2, julio-diciembre 2016, pp. 651-687

ISSN 0066-5061, doi:10.3989/aem.2016.46.2.03 
Romero Abao, Antonio del Rocío (1991), Las fiestas de Sevilla en el siglo XV, Madrid, Deimos.

Rosa y López, Simón de la (1904), Los seises de la catedral de Sevilla, Sevilla, Francisco de P. Díaz.

Ruiz Jiménez, Juan (1997), Música y devoción en Granada (siglos XVI-XVIII): funcionamiento "extravagante" y tipología de plazas no asalariadas en las capillas musicales eclesiásticas de la ciudad, "Anuario Musical" 52, pp. 39-75.

Ruiz Jiménez, Juan (2004), Ministriles y extravagantes en la celebración religio$s a$, en Griffiths, John; Suárez-Pajares, Javier (eds.), Políticas y prácticas musicales en el mundo de Felipe II, Madrid, ICCMU, pp. 199-242.

Ruiz Jiménez, Juan (2007), La librería de canto de órgano. Creación y pervivencia del repertorio del Renacimiento en la actividad musical de la catedral de Sevilla, Granada, Junta de Andalucía.

Ruiz Jiménez, Juan (2008), From Mozos de Coro toward Seises: Boys in the Musical Life of Seville Cathedral in the fifteenth and sixteenth centuries, en Boynton, Susann; Rice, Eric (eds.), Young Choristers, Woodbridge, Boydell and Brewer, pp. 86-103.

Ruiz Jiménez, Juan (2009), Power and musical exchanges: the Dukes of Medina Sidonia in Renaissance Seville, "Early Music" 37, pp. 401-416.

Ruiz Jiménez, Juan (2010), The sounds of the hollow mountain: musical tradition and innovation in Seville cathedral in the early Renaissance, "Early Music History" 29, pp. 189-240.

Ruiz Jiménez, Juan (2014), Música tras la muerte: dotaciones privadas y espacios rituales en la catedral de Sevilla (siglos XIII-XVI), "Revista de Musicología" 37/1, pp. 53-88.

Sánchez Arjona, José (1898), Anales del teatro en Sevilla desde Lope de Rueda hasta fines del siglo XVII, Sevilla, Enrique Rasco.

Sánchez Herrero, José (1989), Algunos elementos de la religiosidad cristiana popular andaluza durante la Edad Media, en Álvarez Santaló, Carlos; Buxó i Rey, María Jesús; Rodríguez Becerra, Salvador (coords.), La religiosidad popular. Antropología e Historia, Barcelona, Anthropos, vol. I, pp. 269-307.

Sánchez Herrero, José (1992), Los años refundacionales del cristianismo en la ciudad y diócesis de Sevilla, 1248-1286, en Ros, Carlos (dir.), Historia de la Iglesia de Sevilla, Sevilla, Castillejo, pp. 103-166.

Sanz Serrano, María Jesús (1997), El Corpus de Sevilla a mediados del siglo XVI. Castillos y danzas, "Laboratorio de Arte" 10, pp. 123-137.

Sanz Serrano, María Jesús (2007), La procesión del Corpus en Sevilla. Influencias sociales y políticas en la evolución del cortejo, "Ars Longa” 16, pp. 55-72.

ANUARIO de Estudios Medievales, 46/2, julio-diciembre 2016, pp. 651-687 ISSN 0066-5061, doi:10.3989/aem.2016.46.2.03 
Sentaurens, Jean, 1984, Seville et le theatre de la fin du Moyen Âge a la fin $d u$ XVIIe siècle, Lille, Atelier National de Reproduction des Theses.

Sherr, Richard (ed.) (1998), Papal Music and musicians in Late Medieval and Renaissance Rome, Oxford, Clarendon Press.

Stevenson, Robert (1985), La música en la Catedral de Sevilla 1478-1606: documentos para su estudio, Madrid, Sociedad Española de Musicología.

Stevenson, Robert (1993), La música en las catedrales españolas del Siglo de Oro, Madrid, Alianza Editorial.

Strohm, Reinhard (1990), Music in late medieval Bruges, Oxford, Clarendon.

Tenorio Cerero, Nicolás (1901), El concejo de Sevilla. Estudio de la organización político-social de la ciudad desde su reconquista hasta el reinado de Alfonso XI (1248-1312), Sevilla, Enrique Rasco.

Tenorio Cerezo, Nicolás (1907), Las milicias de Sevilla, "Archivos, bibliotecas y museos" 17, pp. 222-263.

Whitwell, David (1982), The wind band and wind ensemble before 1500, Northridge, CA, Whitwell Books (History and Literature of the Wind Band and Wind Ensemble series; 1).

Williams, Peter (1993), The organ in western culture (750-1250), Cambridge, Cambridge University Press.

Ybáñez Worboys, Pilar (1999), La fiesta del Corpus en la Málaga de principios del siglo XVI, en López-Guadalupe, Miguel Luis; Cortés, Antonio (eds.), Estudios sobre iglesia y sociedad en Andalucía en la Edad Moderna, Granada, Universidad de Granada, pp. 377-386.

Fecha de recepción del artículo: diciembre 2013

Fecha de aceptación y versión final: julio 2014 